\title{
Influence of natural surfactants on short wind waves in the coastal Peruvian waters
}

\section{Kiefhaber ${ }^{1,2}$, C. J. Zappa ${ }^{3}$, and B. Jähne $e^{1,2}$}

${ }^{1}$ Institute of Environmental Physics, University of Heidelberg, Im Neuenheimer Feld 229, 69120 Heidelberg, Germany

${ }^{2}$ Heidelberg Collaboratory for Image Processing $(\mathrm{HCl})$ at the Interdisciplinary Center for Scientific Computation, University of Heidelberg, Speyerer Str. 6, 69115 Heidelberg, Germany ${ }^{3}$ Lamont-Doherty Earth Observatory, Columbia University, 61 Route 9W, Palisades 10964, NY, USA

Received: 31 May 2015 - Accepted: 02 June 2015 - Published: 03 July 2015

Correspondence to: B. Jähne (bernd.jaehne@iwr.uni-heidelberg.de)

Published by Copernicus Publications on behalf of the European Geosciences Union.

\section{Influence of natural surfactants on short wind waves in the coastal Peruvian waters \\ D. Kiefhaber et al.}

\section{Title Page}

14 4

\section{Full Screen / Esc}

Printer-friendly Version

Interactive Discussion 


\section{Abstract}

Results from measurements of wave slope statistics during the R/V Meteor M91 cruise in the coastal upwelling regions off the coast of Peru are reported. Wave slope probability distributions were measured with an instrument based on the reflection of light at 5 the water surface and a method very similar to the Cox and Munk (1954b) sun glitter technique. During the cruise, the mean square slope (mss) of the waves was found to be very variable, despite the limited range of encountered wind speeds. The Cox and Munk (1954b) parameterization for clean water is found to overestimate mss, but most measurements fall in the range spanned by their clean water and slick parameterizations. The observed variability of mss is attributed to the wave damping effect of surface films, generated by increased biological production in the upwelling zones. The small footprint and high temporal resolution of the measurement allows for tracking abrupt changes in conditions caused by the often patchy structure of the surface films.

\section{Introduction}

15 More than two thirds of the earth's surface are covered by oceans. As the largest interface between the two most important compartments of the system earth - the ocean and the atmosphere - the ocean surface plays an eminent role. Processes taking place in the vicinity of the surface control the transport between the atmosphere and the ocean. This includes the exchange of momentum, sensible and latent heat, and volatile chemical species including environmentally relevant species $\left(\mathrm{CO}_{2}\right.$, methane, halocarbons, dimethylsulfide (DMS), oxidized volatile hydrocarbons, ...).

On both sides of the ocean surface, momentum, heat and mass boundary layers are formed, in which molecular diffusion is the dominant transport mechanism. The thickness of these layers controls the speed of exchange (transfer velocity) and depends on a multitude of factors and processes that cause near-surface turbulence (Jähne, 2012; Garbe et al., 2014). Because wind is driving all the exchange processes, most

OSD

12, 1291-1325, 2015

Influence of natural surfactants on short wind waves in the coastal Peruvian waters

D. Kiefhaber et al.

\section{Title Page}

Abstract Introduction

Conclusions References

Tables Figures

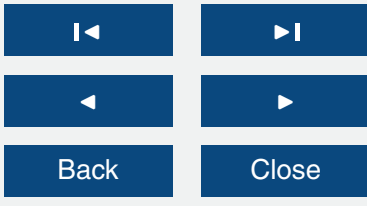

Full Screen / Esc

Printer-friendly Version

Interactive Discussion 
field and laboratory experiments in the last decades focused on relationships between the gas transfer velocity $k$ and wind speed at $10 \mathrm{~m}$. Among the most prominent parameterizations are those of Liss and Merlivat (1986); Wanninkhof (1992), and Ho et al. (2011).

5 However, any recent data collection shows significant deviations of the measured transfer velocities from a simple $k\left(U_{10}\right)$-relationship (Garbe et al., 2014), most recently with data from the Baltic Sea (Schimpf et al., 2011). This variability is obviously caused by the diversified conditions at the water surface at the same wind speed, for example due to different degrees of contamination by surface active material and the sea state.

10 Early attempts to find an improved parameterization simply related the gas transfer velocity to the mean square slope of wind waves as a global measure for the degree of nonlinearity of the system (Jähne et al., 1987). This approach seemed to be promising, but additional, more detailed studies gave a more differentiated picture (Bock et al., 1999). Frew et al. (2004) found that the mean square slope is a better parameter than 15 wind speed (especially to account for surface films), but scatter in the data is still significant. From field and laboratory studies, other parameters have been identified which seem promising for predicting transfer velocities under different conditions, e.g. the turbulent kinetic energy dissipation rate (Zappa et al., 2007) and surface divergence (McKenna and McGillis, 2004). However, as these parameters are very difficult to measure in field experiments, the best way to account for the effect of wind waves on gas exchange is to characterize the roughness of the surface by measuring the mean square slope.

Many optical techniques have been developed to measure the characteristics of short wind waves. This includes wave slope imaging by light reflection, known as Stilwell photography (Stilwell, 1969) and its variants using polarimetric imaging (Zappa et al., 2008; Laxague et al., 2015), stereo imaging (Kohlschütter, 1906; Banner et al., 1989; Benetazzo et al., 2012; Campbell et al., 2014), and wave slope imaging using light refraction (Jähne and Riemer, 1990; Kiefhaber et al., 2014). While the latter technique has found extensive use in wind/wave facilities, only one attempt is reported to

OSD

12, 1291-1325, 2015

Influence of natural surfactants on short wind waves in the coastal Peruvian waters

D. Kiefhaber et al.

\section{Title Page}

Abstract Introduction Conclusions References

Tables Figures

14

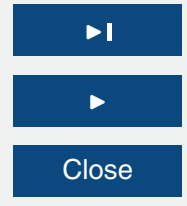

Back

Full Screen / Esc

Printer-friendly Version

Interactive Discussion

1293 
use this technique at sea (Klinke and Jähne, 1995). All of these complex measurement systems are capable to deliver very detailed information on waves on the water surface, but are difficult to operate in shipborne experiments.

The most successful techniques applied at sea (apart from wire gauges) are rather 5 simple ones, based on light reflection and providing statistical parameters describing the waves. But even these parameters, such as the mean square slope, are very useful for a better understanding of air-water gas transfer and give much better insight into exchange processes than measuring wind speed alone.

The statistical measurement of wave slope has a long history dating back to the 10 well-known pioneering work of Cox and Munk (1954a). Their analysis of photographs of sun glitter on the water surface taken from a plane over the Pacific Ocean yielded an empirical description of the wave slope probability density function (PDF) that is still widely used. The PDF is expressed as a truncated Gram-Charlier expansion, in which skewness and peakedness terms are added to a Gaussian distribution.

15 While the data set of Cox and Munk (CM) is limited to a few measurements, more recently, their sun glitter method has been applied to the analysis of large numbers of satellite images. While the results of Bréon and Henriot (2006) mostly agree with the CM parameterization, Ebuchi and Kizu (2002) find generally narrower distributions and less directivity with respect to the alongwind/crosswind direction. The question of the universality of the CM parameterization is also raised by Zappa et al. (2012), who find that surface currents may have an influence on the relation between wind speed and the mean square slope given by $\mathrm{CM}$.

This paper introduces a simple imaging technique to measure the mean square slope and other parameters of short wind waves. The temporal resolution for the measurements is on the order of minutes, the footprint on the water surface is a few square meters. This allows direct comparison with locally measuring techniques to determine gas transfer velocities, such as thermographic measurements with the Active Controlled Flux Technique (Schimpf et al., 2011; Nagel et al., 2015). Section 2 details the measuring principle, the setup of the instrument, calibration, and data processing. The
OSD

12, 1291-1325, 2015

Influence of natural surfactants on short wind waves in the coastal Peruvian waters

D. Kiefhaber et al.

\section{Title Page}

Abstract Introduction

Conclusions References

Tables Figures

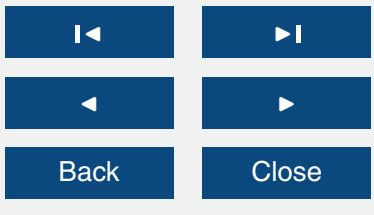

Full Screen / Esc

Printer-friendly Version

Interactive Discussion 
results from the M91 cruise on R/V Meteor are reported in Sect. 3. This includes mean square slopes, a damping factor describing the influence of surface active material, the anisotropy of the surface slope probability distribution, and the short-scale spatial variation of wave parameters related to the patchiness of the surface coverage by surface 5 active material.

\section{Method}

\subsection{Slope statistics measurement}

The measurement method used in this study is related to that of Cox and Munk (1954b) (CM), but instead of the sun uses an artificial light source placed at a finite distance 10 from the water surface, similar to the early work of Schooley (1954). A sketch of the measurement principle is shown in Fig. 1. A camera and a light source are placed at virtually the same location. The camera is observing reflections of the light source on the water surface. Due to the fully specular, i.e. mirror-like, nature of reflections at the water surface, for every light ray, the reflected angle $(\gamma)$ equals the incident angle $(\beta)$.

15 For a setup where the emitter (light source) and detector (camera) are placed at the same location, light is only detected if the surface normal of the water surface points towards the position of emitter and detector. Thus, whenever a speckle (a distorted, reflected image of the light source) is visible at a location $u$ in the image, the wave slope must be $s=\tan \alpha=u / f$, where $\alpha$ is the angle between the surface normal and the vertical and $f$ is the focal length of the camera lens, see inset in Fig. 1. In two dimensions, this becomes

$s=\left(\begin{array}{l}s_{x} \\ s_{y}\end{array}\right)=\frac{1}{f}\left(\begin{array}{l}u \\ v\end{array}\right)$

with the image coordinates $u$ and $v$. Thus, for every speckle that is visible in the image, the slope of the water surface at the point of reflection is known - independent of the
OSD

12, 1291-1325, 2015

Influence of natural surfactants on short wind waves in the coastal Peruvian waters

D. Kiefhaber et al.

\section{Title Page}

Abstract Introduction

Conclusions References

Tables Figures

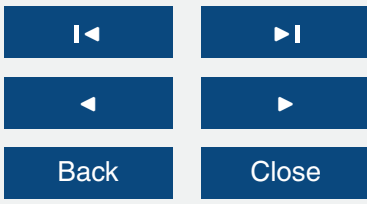

Full Screen / Esc

Printer-friendly Version

Interactive Discussion 
distance to the water surface. By averaging many snapshots of reflections from the water surface, the probability of slopes can be determined from the probability of the occurrence of speckles at certain positions in the images.

A major difference between the CM method and the principle used in this study is the 5 nature of the statistical averaging process. CM measured from an airplane flying at an

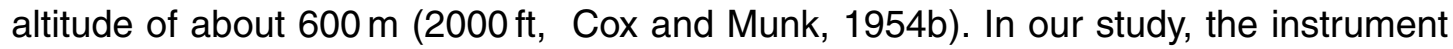
was placed at a distance of $8 \mathrm{~m}$ to the water surface on the bow of research vessel R/V Meteor. While in the photographs of $\mathrm{CM}$, many water surface facets contributed to the signal at each point in the image, our images resolve speckles coming from the smallest

10 ripples. Thus, while CM derived a PDF from a single photograph, implicitly assuming homogeneous conditions over a larger area on the Ocean surface, our method relies on conditions to be stationary for a certain time (typically 5-30 min) at a small footprint of a few square meters. As will be discussed later, an open question is how representative the conditions at the measurement spot are when larger scales are of interest.

\subsection{Instrument}

Figure 2 shows the instrument that was built for the measurement of wave statistics during the R/V Meteor M91 cruise. A Basler acA2500-14gm monochrome gigabit ethernet camera with $2592 \times 1944$ pixels and a maximum frame rate of $14 \mathrm{~Hz}$ is placed at the center of an LED array built from 182 OSRAM SFH 4715S high power infrared $(850 \mathrm{~nm})$ emitters. To collimate the light, Carclo $10 \mathrm{~mm}$ Medium Spot Frosted lenses (\#10413) are placed on each LED, decreasing their half angle to $\pm 25^{\circ}$. The lens used (Schneider Kreuznach Cinegon 1.4/8) had a focal length of $8.2 \mathrm{~mm}$ that gives a field of view of $38^{\circ} \times 30^{\circ}$. A near-infrared band-pass filter, matched to the emission spectrum of the LEDs, is used to suppress ambient light.

25 Camera and light source are integrated into the Reflective Stereo Slope Gauge (Kiefhaber, 2014) with its two line shaped light sources and cameras. The RSSG was also used in this study and is capable of measuring wave heights by stereo triangulation, as well as the probability of zero surface slope, from which a surface rough-
OSD

$12,1291-1325,2015$

Influence of natural surfactants on short wind waves in the coastal Peruvian waters

D. Kiefhaber et al.

\section{Title Page}

Abstract Introduction

Conclusions References

Tables Figures

14 4

Back Close

Printer-friendly Version

Interactive Discussion 
ness parameter $\chi$ which is proportional to the mean square slope can be estimated (Kiefhaber et al., 2015).

During M91, the instruments were installed at the bow of R/V Meteor (see Fig. 2). The cameras were facing down to the water surface. To avoid interference of the waves 5 with the research vessel, the vessel was moving forward and against the direction of the wind at a speed of 1-2 kn during measurements. In the derivation of the method in Eq. (1), it was tacitly assumed that the camera is looking down vertically, with its image plane parallel to the mean water level. On a moving ship, this is not the case at a given moment. The ship's pitch and roll need to be measured and accounted for in data processing. Ship motion was recorded with a Crossbow VG400 inertial measurement unit (IMU) that was located next to the RSSG at the bow of R/V Meteor.

\subsection{Data processing}

\subsubsection{Wave height correction}

In Eq. (1), a simple relation between the image position at which a speckle is visible 15 and the slope of the water surface at the point of reflection is given. This relation is independent of wave height. However, the brightness of the speckles in the image is not, it is proportional to $1 / R^{2}$, where $R$ is the distance of the camera/light source to the water surface. This causes a bias in the averaging process, speckles coming from reflections at wave crests have a bigger impact than those coming from wave troughs.
With the Reflective Stereo Slope Gauge (RSSG), the distance to the water surface is measured and the bias is then removed. The average intensity of speckles at position $(u, v)$ in the image can thus be expressed as

$I(u, v) \propto \frac{1}{R^{2}} p\left(s_{x}(u, v), s_{y}(u, v)\right)$,

with the two-dimensional probability density function (PDF) $p\left(s_{x}, s_{y}\right)$ of wave slope.
OSD

$12,1291-1325,2015$

Influence of natural surfactants on short wind waves in the coastal Peruvian waters

D. Kiefhaber et al.

\section{Title Page}

Abstract Introduction

Conclusions References

Tables Figures

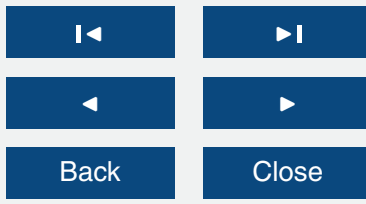

Full Screen / Esc

Printer-friendly Version

Interactive Discussion 


\subsubsection{Ship motion compensation}

The simple relation between wave slope and speckle position given in Eq. (1) also does not account for a tilt of the instrument due to the pitch and roll of the ship. Their effect on the measurement can be understood easily with the help of Fig. 3. If the instrument

5 is tilted by the angle $\rho$ (right side), the relation in Eq. (1) has to be adapted

$s_{x}=\tan \alpha=u / f \rightarrow \tan (\alpha+\rho)=u / f$.

Fortunately, as pitch and roll are usually small, it is possible to approximate the tangent without causing large errors,

$\tan (\alpha+\rho) \approx \tan (\alpha)+\rho$

10 In this approximation, pitch and roll simply add an offset to the image position-to-slope relation. Or, looked at from another side, the occurence of slope $s_{X}$ will cause a speckle at image position $(u-f \rho)$ :

$s_{X}=\tan \alpha=(u-f \rho) / f$.

This dependence can be easily accounted for during the averaging process (Kiefhaber, 15 2014). Pitch and roll are computed from the raw IMU accelerometer and gyroscope output following the method of Edson et al. (1998) and Miller et al. (2008).

\subsubsection{Radiometric calibration}

The LED light source does not emit isotropically, but has a defined angular emission distribution. This angular distribution was measured and a calibration matrix was com20 puted. For every pixel, this matrix holds a weighting factor which compensates for the decrease of speckle brightness towards the image corners due to a decrease of emitted intensity of the light source at higher angles (for more information, see Kiefhaber, 2014).

OSD

12, 1291-1325, 2015

Influence of natural surfactants on short wind waves in the coastal Peruvian waters

D. Kiefhaber et al.

\section{Title Page}

Abstract Introduction

Conclusions References

Tables Figures

14

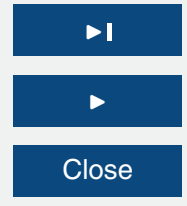

Back

Close

Full Screen / Esc

Printer-friendly Version

Interactive Discussion 


\subsubsection{Statistical analysis}

During the measurements, speckle images are acquired continuously at a frequency of $10 \mathrm{~Hz}$. This continuous data stream is divided into chunks of 5 min length, for which probability distributions are computed.

$5 \quad$ An example is given in Fig. 4. The false color image shows the measured 2-D probability distribution, which is computed from the speckle images after applying the wave height and pitch and roll correction, as well as the radiometric calibration. The wind direction is marked by the close to vertical line, the wind is blowing in the direction from top to bottom of the image. In the upper and right panels, cross sections through the

2-D distribution are plotted, taken along the two white lines. The black lines in those profiles show the result of the fit of a model PDF to the 2-D dataset. The model PDF is a truncated Gram-Charlier expansion, similar to the one used by Cox and Munk (1954a), but omitting the peakedness terms. The used model PDF is

$p(\xi, \eta)=A \cdot \exp \left[-\frac{1}{2}\left(\xi^{2}+\eta^{2}\right)\right]\left[1-\frac{1}{2} c_{21}\left(\xi^{2}-1\right) \eta-\frac{1}{6} c_{03}\left(\eta^{3}-3 \eta\right)\right]+O$

15 where normalized coordinates $\xi=\left(s_{x}-s_{x}, 0\right) / \sigma_{c}$ and $\eta=\left(s_{y}-s_{y}, 0\right) / \sigma_{a}$ have been used and $\sigma_{c}$ and $\sigma_{a}$ are the standard deviation of the slope distribution in the crosswind and alongwind direction, respectively. In addition to the two terms for the skewness in the alongwind direction with coefficients $c_{21}, c_{03}$, an additive offset $O$, as well as two shifts of the origin of the coordinate system $x_{0}$ and $y_{0}$ are allowed. These were necessary, as the position of slope zero could not be determined to the required precision on the moving ship. Before deployment to the Meteor M91 cruise, the system was tested and its measurement principle validated under controlled conditions in the laboratory (see Appendix A).

\section{OSD}

$12,1291-1325,2015$

Influence of natural surfactants on short wind waves in the coastal Peruvian waters

D. Kiefhaber et al.

\section{Title Page}

Abstract Introduction

Conclusions References

Tables Figures

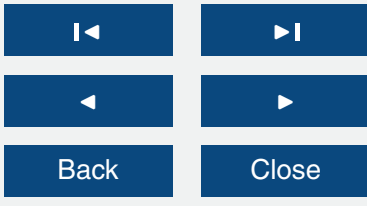

Full Screen / Esc

Printer-friendly Version

Interactive Discussion 


\section{Results and discussion}

\subsection{Measurements during M91}

The wave slope statistics instrument was installed at the bow of the German research vessel R/V Meteor during the M91 cruise in December 2012. The cruise explored the

5 coastal upwelling regions off Peru. Both its departure and final destination were the port of Callao, Peru. During the cruise, wave slope statistics were collected whenever the micro-structure probe was deployed and the ship was moving at a slow pace of 1-2 kn upwind. This guaranteed minimal interaction between the waves in the footprint of the camera and the ship itself. During casts with the CTD rosette, however, Meteor's $360^{\circ}$ bow thruster was used to hold the position and interfered massively with water flow and waves around the bow of the ship, making measurements impossible.

Measurements are presented from a total of 30 stations. Slope probability distributions are available for all night-time stations, as daylight affected the measurements. However, the most important statistical parameter, the mean square slope $\sigma_{s}^{2}$ was determined for all stations with the help of the RSSG. The measurements of the RSSG are not affected by daylight, as it uses a spectral band around $950 \mathrm{~nm}$, in which light is effectively absorbed by water vapour in the atmosphere. Only in conditions when sun glint is visible in the RSSG images can the data not be processed. The RSSG measures the probability for slope zero, its inverse, the surface roughness parameter

$20 \quad \chi$ is proportional to mss (Kiefhaber et al., 2015). The proportionality constant is calibrated against the night-time measurements of the probability density functions (see Appendix B). An overview of the stations for which processed measurements are available is given in Table 1.

\subsection{Mean square slope and wind speed}

25 Figure 5 shows all available mean square slope (mss) measurements from the M91 cruise. Green diamonds are mss values extracted from slope PDFs, where mss is
OSD

$12,1291-1325,2015$

Influence of natural surfactants on short wind waves in the coastal Peruvian waters

D. Kiefhaber et al.

\section{Title Page}

Abstract Introduction

Conclusions References

Tables Figures

14 4

\section{Full Screen / Esc}

Printer-friendly Version

Interactive Discussion 
obtained as a parameter of the fit of the model function given in Eq. (6). Blue circles are additional measurements with the RSSG, where the mss is estimated from the probability of slope zero. The solid and dashed black lines represent the Cox and Munk (CM) parameterizations of mss with wind speed for clean water and surface slicks, 5 respectively (Cox and Munk, 1954a). The error of the mss measurements from the PDF method (diamond symbols) was estimated to be less than $4 \%$ from laboratory data under controlled conditions (Kiefhaber, 2014).

Most of the measurements fall in between the two parameterizations. A notable exception are the open green symbols. These are measurements from a single station 10 (\#1775-2, see Table 1) under very complex conditions. Strong currents, large swell and high wind speeds, all from different directions likely led to disturbances of the measurement by the vessel itself. Neglecting those data points, the CM clean parameterization is found to overestimate mss.

The scatter in the data set is not surprising, in fact, compared to results from other 15 more recent studies (Zappa et al., 2012; Laxague et al., 2015), the correlation of mss and wind is relatively good. Nevertheless, it is obvious that there is no simple relationship between surface roughness (mss) and wind speed. Particularly in the upwelling regions in the Peruvian coastal waters, high biological activity leads to a strong production of surface active material. It is well known from many laboratory and field studies that these surface films inhibit small-scale waves and reduce surface roughness (Hühnerfuss et al., 1987).

The missing direct link between wind speed and mss also has consequences for air-sea interaction studies. Transfer velocities have been found to scale better with mss than with wind speed, especially for the range of wind speeds observed during M91 and under the influence of surfactants (e.g. Frew et al., 2004). Thus, one consequence of the observed ambiguity of the mss to wind speed relation is that using wind speed only parameterizations to estimate (local) transfer velocities will cause large errors. These transfer velocities are required to estimate trace gas fluxes across the water surface from the measurement of air-water concentration differences. Therefore, the
OSD

12, 1291-1325, 2015

Influence of natural

surfactants on short wind waves in the

coastal Peruvian

waters

D. Kiefhaber et al.

\section{Title Page}

Abstract

Introduction

Conclusions

References

Tables

Figures

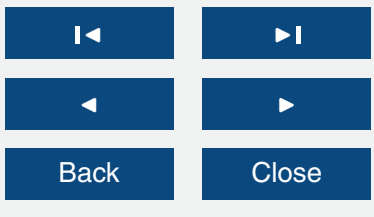

Full Screen / Esc

Printer-friendly Version

Interactive Discussion 
large errors associated with the transfer velocities propagate into large errors in the computed fluxes.

OSD

\subsection{Anisotropy of the wave slope probability distribution}

Waves typically have higher slopes in the alongwind than in the crosswind direction. 5 The anisotropy parameter $\gamma=\sigma_{\mathrm{a}}^{2} / \sigma_{\mathrm{c}}^{2}$ is the ratio between the mss in the alongwind direction, $\sigma_{\mathrm{a}}^{2}$, and the crosswind $\mathrm{mss}\left(\sigma_{\mathrm{c}}^{2}\right)$. Cox and Munk (1954a) report $\gamma$ to lie between 1.0 and 0.62 . Bréon and Henriot (2006) give relationships of the mss components with wind speed in their much larger dataset of 8 million globaly distributed satellite images, from which Munk (2009) computes a functional dependence of $\gamma$ on the inverse wind 10 speed

$\gamma=0.585+0.76 U_{10}^{-1}$

Despite the large scatter in the data, Fig. 6 shows that our dataset does not agree with this parameterization. No clear trend with wind speed is visible, the mean value is $\gamma_{\text {mean }}=0.82$. CM speculate that increased anisotropy (lower $\gamma$ ) should be the con15 sequence of steady blowing winds, while gustiness should lead to more isotropic wave fields. During M91, wind conditions were usually relatively stable. Wind speed data is only available as one-minute mean values, so that gustiness is hard to estimate. The data set was classified into two subsets of similar size. Open circles represent measurements during which the standard deviation of wind speed was less than $4 \%$ of the mean, solid circles measurements were variability was greater. No clear trend between the two groups is visible. The overall relatively high values of $\gamma$ are likely also due to the fact that we encountered mostly rather mature seas, as it is well known, e.g. from our own laboratory validation experiment that young, growing waves have larger anisotropy (see Appendix A).

25 Only a weak asymmetry between the alongwind and crosswind mss is reported also by Ebuchi and Kizu (2002). They find two possible explanations for the discrepancy
12, 1291-1325, 2015

Influence of natural surfactants on short wind waves in the coastal Peruvian waters

D. Kiefhaber et al.

\section{Title Page}

Abstract Introduction

Conclusions References

Tables Figures

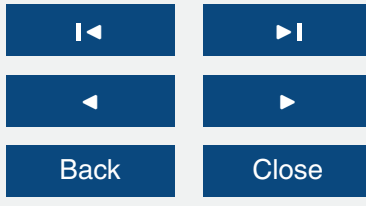

Full Screen / Esc

Printer-friendly Version

Interactive Discussion 
between their data and the $\mathrm{CM}$ results. One, they argue that $\mathrm{CM}$ were measuring waves that were not in equilibrium with the wind but still growing, leading to higher asymmetry. And two, the spatial resolution of their (satellite) data set is only $0.25^{\circ} \times 0.25^{\circ}$ and the variability of wind directions over this large area may smear out the asymmetry. In the 5 data presented here, the spatial resolution is much higher than that of any of the other studies, but due to the temporal averaging that is necessary to measure the slope PDF, variability of the wind speed and direction could have an impact. As was noted above, wind speeds and directions were quite constant during the M91 cruise and their variability are not likely to be the source for a low asymmetry. The other consequence of

10 the conditions encountered with steady winds at moderate wind speeds is that waves were likely in equilibrium with the wind for most of the measurements. Thus, the data set of M91 is certainly not universally valid. Still, the disagreement with other data sets underlines that many factors affect the slope PDF and simple relations may not be able to capture all the complex interactions.

\subsection{Spatial distribution of surface films}

During the M91 cruise, R/V Meteor probed the Peruvian coastal waters in multiple transects orthogonal to the coast line. Figure 7 shows the geographic location of all the stations for which wave slope data was processed. The color code of the data points represents the fraction

$20 \epsilon=\sigma_{\mathrm{s}}^{2} / \sigma_{\mathrm{S}, \mathrm{CM}}^{2}$,

where $\sigma_{\mathrm{s}}^{2}$ is the average mss of all measurements at a particular station and $\sigma_{\mathrm{S}, \mathrm{CM}}^{2}$ is the mss expected from the clean water CM parameterization for the average wind speed at the station. Thus, the lower the value of $\epsilon$, the more likely it is that a surface film is damping the waves to reduce surface roughness. The data set is sparse and no clear trend of reduced roughness in rather coastal waters compared to more open ocean conditions is visible, although it appears that there are two hot spots with low values of $\epsilon$ in the North $\left(6^{\circ} \mathrm{S}\right)$ and center (between 10 and $12^{\circ} \mathrm{S}$ ) of the study area.
OSD

12, 1291-1325, 2015

Influence of natural surfactants on short wind waves in the coastal Peruvian waters

D. Kiefhaber et al.

\section{Title Page}

Abstract Introduction

Conclusions References

Tables Figures

14

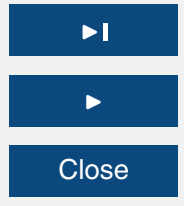

Back

Close

Full Screen / Esc

Printer-friendly Version

Interactive Discussion 
It is expected that surface roughness is reduced particularly in upwelling areas, where biological activity is high. To investigate this, Fig. 8 shows $\epsilon$ over the water temperature, as upwelling areas have lower relative ocean temperatures. Values of $\epsilon$ are obviously lower on average for lower water temperatures, which correspond to up5 welling zones. The notable outlier at about $18^{\circ} \mathrm{C}$ with a value of 1.16 , which is the dark red point close to the coast in Fig. 7 , occurred at very low wind speeds (estimated $U_{10}=1.8 \mathrm{~ms}^{-1}$ ). Under these conditions, the CM relation may not be dependable and influences such as temperature stratification may severely alter the wind profile between a height of $35 \mathrm{~m}$, where wind speed was measured, and the water surface. Thus, 10 it is quite possible that the wind speed at the surface corresponded to a different $U_{10}$ wind speed. As mss is relatively small for this range of wind speeds, even a small absolute error has large consequences for $\epsilon$. At higher water temperatures, the scatter in $\epsilon$ increases, but values as low as 0.6 occur throughout the temperature range encountered during M91. This demonstrates that reduced surface roughness is pronounced 15 in upwelling zones, but not limited to these.

\subsection{Surface films on smaller scales}

During M91, at some stations very inhomogeneous surface conditions were encountered. An example is shown in Fig. 9, where isolated patches of reduced surface roughness are clearly visible. Under these conditions, exchange processes are also expected 20 to be highly inhomogeneous. This poses a challenge for all types of air-sea interaction measurements which average over a larger footprint, from direct covariance (McGillis et al., 2001; Edson et al., 2011) to dual tracers (Wanninkhof et al., 2009; Ho et al., 2011) but also for estimating air-sea fluxes from the measurement of air-water concentration gradients (Kock et al., 2012; Quack et al., 2004). The exact footprint over 25 which measurements using these methods are averaged is not easy to determine and homogeneity of conditions usually has to be assumed. Local measurements of transfer velocities are possible with the Active Controlled Flux Technique (e.g. Schimpf et al., 2011; Nagel et al., 2015), which has a well-defined footprint of about $1 \mathrm{~m}^{2}$. ACFT mea-

\section{OSD}

$12,1291-1325,2015$

Influence of natural surfactants on short wind waves in the coastal Peruvian waters

D. Kiefhaber et al.

\section{Title Page}

Abstract Introduction

Conclusions References

Tables Figures

14 4

Back Close

Printer-friendly Version

Interactive Discussion 
surements were also performed during the M91 cruise using the same measurement footprint as the wave slope system. Results for these measurements will be the subject of a future publication. To estimate local transfer velocities, a certain amount of temporal averaging is required. Under conditions such as in Fig. 9, when the slick patches 5 are moving relative to the ship, it is important to have time resolved measurements of surface roughness to allow to separate slick from non-slick conditions in the averaging process. Figure 10 shows an approach to achieve this. The mean brightness of speckles in RSSG images was computed and its change over a time span of $5 \mathrm{~min}$ is plotted. The raw signal is very variable, but the shown running mean has a clear trend. 10 About $150 \mathrm{~s}$ into the measurement, the ship enters a slick patch, surface roughness suddenly decreases and speckle brightness increases by more than one order of magnitude. The drastic change in surface conditions is also well visible in the two example RSSG images shown in Fig. 11. In these images, speckles appear as dark spots on a white background, as the image gray scale was inverted for better visibility. The left 15 image was acquired before the ship entered the slick patch (first green line in Fig. 10) and a typical wavy surface is visible with many speckles coming from different surface facets. In the right image (taken at the time marked by the second line in Fig. 10), the damping effect of the slick on the small-scale roughness of the water surface is clearly visible. The line-like shape of the light source (see Fig. 2) dominates the shape of the speckles, meaning that the water surface is almost flat, like a slightly bent mirror.

The shown time series is just one of many examples of sudden changes of the surface roughness encountered during M91, other series show that spatial scales of surface film patches can be on the order of $100 \mathrm{~m}$ (Kiefhaber, 2014). On one hand, these rapidly changing conditions pose additional challenges to the estimation of airsea interaction processes, but on the other hand, the results also show that changes can be tracked on very short time scales by suitable wave statistics measurements.
OSD

$12,1291-1325,2015$

Influence of natural surfactants on short wind waves in the coastal Peruvian waters

D. Kiefhaber et al.

\section{Title Page}

Abstract Introduction

Conclusions References

Tables Figures

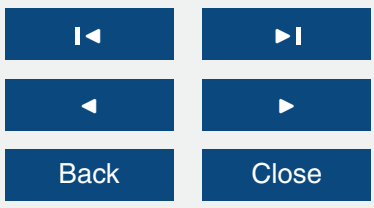

Full Screen / Esc

Printer-friendly Version

Interactive Discussion 


\section{Conclusions}

The Reflective Stereo Slope Gauge (RSSG, Kiefhaber, 2014) and the wave slope probability distribution measurements provide useful wave slope statistics at a small footprint and with high temporal resolution. This information is particularly useful in 5 combination with local measurements of transfer velocities by active thermography, which were conducted at the same footprint and are the subject of a future paper.

The small footprint of the measurement allows to resolve the patchiness of the surface coverage with surface active material from biological production. Surfactant coverage not only leads to the damping of wind waves which is visible in the wave slope measurements, but also reduces the gas transfer velocity and thus the exchange of trace gases between ocean and atmosphere.

During the M91 cruise, a large variability of surface conditions was encountered that can not simply be explained by variances in the wind speed. A corresponding large variation of gas transfer velocities is expected. In laboratory studies, differences up to

15 a factor of three are found between clean water and surface slick cases for the low to moderate wind speeds encountered during M91 (Krall, 2013).

During M91, R/V Meteor was moving forward at a slow pace for the wave statistics measurements. Given the high temporal resolution of the surfactant coverage measurements, the system could be used in future measurements to map the distribution of surface films on larger water surface areas, either from a research vessel or a small and low flying drone. Statistical measurements of wave slope will also be a standard component of future transfer velocity measurements with the Active Controlled Flux Technique (ACFT).

\section{Appendix A: Slope PDF measurement validation}

25 The slope PDF measuring instrument was deployed to a laboratory experiment in the wind-wave facility in Marseille-Luminy, France in September 2012. There, slope prob-
OSD

12, 1291-1325, 2015

Influence of natural surfactants on short wind waves in the coastal Peruvian waters

D. Kiefhaber et al.

\section{Title Page}

Abstract Introduction

Conclusions References

Tables Figures

14

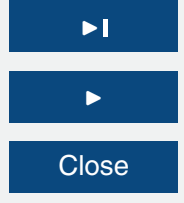

Back

Close

Full Screen / Esc

Printer-friendly Version

Interactive Discussion 
ability distributions were measured under controlled conditions. From an earlier experiment, measurements of the mean square slope with a Laser slope gauge (LSG) were available (Kiefhaber et al., 2015). This reference data set is used to validate the mean square slope extraction by fitting a model function to the measured probability 5 distribution. Figure 12 shows the overall good agreement of both methods. Shown are the total mean square slope (squares), as well as the alongwind (downward triangles) and crosswind (upward triangles) mean square slopes for the the probability distribution method $\left(\sigma_{\mathrm{PD}}^{2}\right)$ and the reference Laser slope gauge $\left(\sigma_{\mathrm{LSG}}^{2}\right)$. Deviations at higher alongwind mss are due to the strongly non-Gaussian shape of the distribution at these o conditions, which is caused by the very young (and steep) waves in the laboratory facility at a fetch of $27 \mathrm{~m}$.

\section{Appendix B: RSSG mss calibration}

The Reflective Stereo Slope Gauge (RSSG) measures a surface roughness parameter $(\chi)$ which is proportional to the mss and derived from the probability for zero slope 15 (Kiefhaber et al., 2015). Unlike the wave probability distribution measurements, the RSSG is not impacted by daylight, unless there is sun glint in the image. Therefore, the data set collected with the RSSG during M91 is larger than that of the probability distribution measurements. However, using the available PDF measurements, it is possible to absolutely calibrate the factor linking $\chi$ to the mss. The calibration result is shown in 20 Fig. 13. There is overall good correlation between $\chi$ and mss $\sigma_{\mathrm{s}}^{2}$, but also a significant amount of scatter, the rms deviation is $5.9 \%$.

Acknowledgements. The authors gratefully acknowledge partial financial support for this research by the German Research Foundation (DFG, grant number Ja395/15-1), as well as the German Federal Ministry of Education and Research (BMBF) joint project "Surface Ocean Prowould like to thank everyone from the M91 science party and crew of R/V Meteor, and in par-

\section{OSD}

12, 1291-1325, 2015

Influence of natural surfactants on short wind waves in the coastal Peruvian waters

D. Kiefhaber et al.

\section{Title Page}

Abstract Introduction

Conclusions References

Tables Figures

14

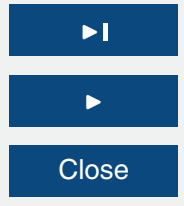

Back

Full Screen / Esc

Printer-friendly Version

Interactive Discussion 
ticular Hermann Bange and Annette Kock for all their efforts and support in the preparation and execution of the experiment.

\section{References}

Banner, M. L., Jones, I. S. F., and Trinder, J. C.: Wavenumber spectra of short gravity waves, J. Fluid Mech., 198, 321-344, doi:10.1017/S0022112089000157, 1989. 1293

Benetazzo, A., Fedele, F., Gallego, G., Shih, P.-C., and Yezzi, A.: Offshore stereo measurements of gravity waves, Coast. Eng., 64, 127-138, doi:10.1016/j.coastaleng.2012.01.007, 2012. 1293

Bock, E. J., Hara, T., Frew, N. M., and McGillis, W. R.: Relationship between air-sea gas transfer 10 and short wind waves, J. Geophys. Res., 104, 25821-25831, doi:10.1029/1999JC900200, 1999. 1293

Bréon, F. M. and Henriot, N.: Spaceborne observations of ocean glint reflectance and modeling of wave slope distributions, J. Geophys. Res., 111, C06005, doi:10.1029/2005JC003343, 2006. 1294, 1302, 1318

15 Campbell, A. J., Bechle, A. J., and Wu, C. H.: Observations of surface waves interacting with ice using stereo imaging, J. Geophys. Res.-Oceans, 119, 3266-3284, doi:10.1002/2014JC009894, 2014. 1293

Cox, C. and Munk, W.: Statistics of the sea surface derived from sun glitter, J. Marine Res., 13, 198-227, 1954a. 1294, 1299, 1301, 1302

Cox, C. and Munk, W.: Measurements of the roughness of the sea surface from photographs of the sun's glitter, J. Opt. Soc. Am., 44, 838-850, doi:10.1364/JOSA.44.000838, 1954b. 1292, 1295, 1296, 1317

Ebuchi, N. and Kizu, S.: Probability distribution of surface wave slope derived using sun glitter images from geostationary meteorological satellite and surface vector winds from scatterometers, J. Oceanogr., 58, 477-486, doi:10.1023/A:1021213331788, 2002. 1294, 1302

Edson, J., Fairall, C., Bariteau, L., Helmig, D., Zappa, C., Cifuentes-Lorenzen, A., McGillis, W., Pezoa, S., and Hare, J.: Direct covariance measurement of $\mathrm{CO}_{2}$ gas transfer velocity during the 2008 Southern Ocean Gas Exchange Experiment: wind speed dependency, J. Geophys. Res., 116, C00F10, doi:10.1029/2011JC007022, 2011. 1304

\section{OSD}

12, 1291-1325, 2015

Influence of natural surfactants on short wind waves in the coastal Peruvian waters

D. Kiefhaber et al.

\section{Title Page}

Abstract Introduction

Conclusions References

Tables Figures

14

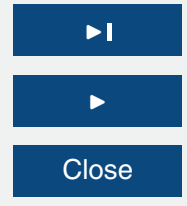

Back

Close

Full Screen / Esc

Printer-friendly Version

Interactive Discussion 
Edson, J. B., Hinton, A. A., Prada, K. E., Hare, J. E., and Fairall, C. W.: Direct covariance flux estimates from moving platforms at sea, J. Atmos. Ocean. Tech., 15, 547-562, doi:10.1175/1520-0426(1998)015<0547:DCFEFM>2.0.CO;2, 1998. 1298

Frew, N., Bock, E., Schimpf, U., Hara, T., Haussecker, H., Edson, J., McGillis, W., Nelson, R., McKenna, S., Uz, B., and Jähne, B.: Air-sea gas transfer: its dependence on wind stress, small-scale roughness, and surface films, J. Geophys. Res., 109, C08S17, doi:10.1029/2003JC002131, 2004. 1293, 1301

Garbe, C. S., Rutgersson, A., Boutin, J., Delille, B., Fairall, C. W., Gruber, N., Hare, J., Ho, D., Johnson, M., de Leeuw, G., Nightingale, P., Pettersson, H., Piskozub, J., Sahlee, E., Tsai, W., Ward, B., Woolf, D. K., and Zappa, C.: Transfer across the air-sea interface, in: OceanAtmosphere Interactions of Gases and Particles, edited by: Liss, P. S. and Johnson, M. T., Springer, 55-112, doi:10.1007/978-3-642-25643-1_2, 2014. 1292, 1293

Hühnerfuss, H., Walter, W., Lange, P., and Alpers, W.: Attenuation of wind waves by monomolecular sea slicks and the Marangoni effect, J. Geophys. Res., 92, 3961-3963, 15 doi:10.1029/JC092iC04p03961, 1987. 1301

Ho, D. T., Wanninkhof, R., Schlosser, P., Ullman, D. S., Hebert, D., and Sullivan, K. F.: Toward a universal relationship between wind speed and gas exchange: Gas transfer velocities measured with 3He/SF6 during the Southern Ocean Gas Exchange Experiment, J. Geophys. Res., 116, C00F04, doi:10.1029/2010JC006854, 2011. 1293, 1304

Jähne, B.: Atmosphere-water exchange, in: Transport and Fate of Chemicals in the Environment - Selected Entries from the Encyclopedia of Sustainability Science and Technology, edited by: Gulliver, J. S., vol. 1, Springer, 175-193, doi:10.1007/978-1-4614-5731-2_8, 2012. 1292

Jähne, B. and Riemer, K.: Two-dimensional wave number spectra of small-scale water surface waves, J. Geophys. Res., 95, 11531-11646, doi:10.1029/JC095iC07p11531, 1990. 1293

Jähne, B., Münnich, K. O., Bösinger, R., Dutzi, A., Huber, W., and Libner, P.: On the parameters influencing air-water gas exchange, J. Geophys. Res., 92, 1937-1950, doi:10.1029/JC092iC02p01937, 1987. 1293

Kiefhaber, D.: Optical measurement of short wind waves - from the laboratory to the field, 30 Dissertation, Institut für Umweltphysik, Fakultät für Physik und Astronomie, Univ. Heidelberg, available at: http://www.ub.uni-heidelberg.de/archiv/16304, 2014. 1296, 1298, 1301, 1305, 1306

\section{OSD}

12, 1291-1325, 2015

\section{Influence of natural \\ surfactants on short wind waves in the \\ coastal Peruvian \\ waters \\ D. Kiefhaber et al.}

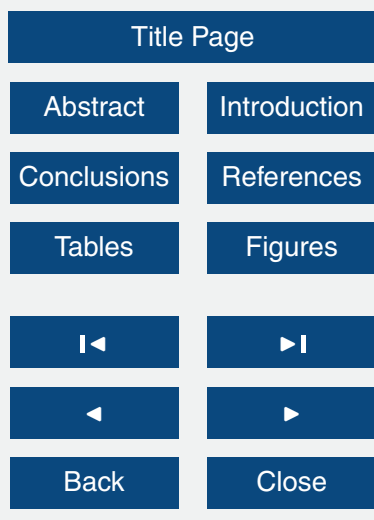

Full Screen / Esc

Printer-friendly Version

Interactive Discussion 
Kiefhaber, D., Reith, S., Rocholz, R., and Jähne, B.: High-speed imaging of short wind waves by shape from refraction, J. Europ. Opt. Soc. Rap. Public., 9, 14015, doi:10.2971/jeos.2014.14015, 2014. 1293

Kiefhaber, D., Caulliez, G., Zappa, C. J., Schaper, J., and Jähne, B.: Water wave measurement from stereo images of specular reflections, Meas. Sci. Technol., submitted, 2015. 1297, 1300,1307

Klinke, J. and Jähne, B.: Measurements of short ocean waves during the MBL ARI West Coast Experiment, in: Air-Water Gas Transfer, Selected Papers, 3rd Intern. Symp. on AirWater Gas Transfer, edited by: Jähne, B. and Monahan, E. C., AEON, Hanau, 165-173, doi:10.5281/zenodo.10399, 1995. 1294

Kock, A., Schafstall, J., Dengler, M., Brandt, P., and Bange, H. W.: Sea-to-air and diapycnal nitrous oxide fluxes in the eastern tropical North Atlantic Ocean, Biogeosciences, 9, 957964, doi:10.5194/bg-9-957-2012, 2012. 1304

Kohlschütter, E.: Die Forschungsreise S. M. S. Planet II. Stereophotogrammetrische Aufnah-

15 men, Annalen der Hydrographie und Maritimen Meterologie, 34, 220-227, 1906. 1293

Krall, K. E.: Laboratory investigations of air-sea gas transfer under a wide range of water surface conditions, Dissertation, Institut für Umweltphysik, Fakultät für Physik und Astronomie, Univ. Heidelberg, available at: http://www.ub.uni-heidelberg.de/archiv/14392, 2013. 1306

Laxague, N. J. M., Haus, B. K., Bogucki, D., and Özgökmen, T.: Spectral characterization of 20 fine-scale wind waves using shipboard optical polarimetry, J. Geophys. Res.-Oceans, 120, 3140-3156, doi:10.1002/2014JC010403, 2015. 1293, 1301

Liss, P. S. and Merlivat, L.: Air-sea gas exchange rates: introduction and synthesis, in: The Role of Air-Sea Exchange in Geochemical Cycling, edited by: Buat-Menard, P., Reidel, Boston, MA, 113-129, doi:10.1007/978-94-009-4738-2_5, 1986. 1293

McGillis, W. R., Edson, J. B., Hare, J. E., and Fairall, C. W.: Direct covariance air-sea $\mathrm{CO}_{2}$ fluxes, J. Geophys. Res., 106, 16729-16745, doi:10.1029/2000JC000506, 2001. 1304

McKenna, S. P. and McGillis, W. R.: The role of free-surface turbulence and surfactants in air-water gas transfer, Int. J. Heat Mass Tran., 47, 539-553, doi:10.1016/j.ijheatmasstransfer.2003.06.001, 2004. 1293

30 Miller, S., Hristov, T., Edson, J., and Friehe, C.: Platform motion effects on measurements of turbulence and air-sea exchange over the open ocean, J. Atmos. Ocean. Tech., 25, 16831694, doi:10.1175/2008JTECHO547.1, 2008. 1298
OSD

$12,1291-1325,2015$

Influence of natural

surfactants on short

wind waves in the

coastal Peruvian

waters

D. Kiefhaber et al.

\section{Title Page}

Abstract

Introduction

Conclusions

References

Tables

Figures

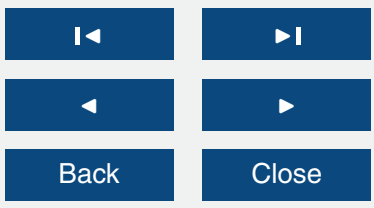

Full Screen / Esc

Printer-friendly Version

Interactive Discussion 
Munk, W.: An inconvenient sea truth: spread, steepness, and skewness of surface slopes, Annu. Rev. Marine Sci., 1, 377-415, doi:10.1146/annurev.marine.010908.163940, 2009. 1302, 1318

Nagel, L., Krall, K. E., and Jähne, B.: Comparative heat and gas exchange measurements 5 in the Heidelberg Aeolotron, a large annular wind-wave tank, Ocean Sci., 11, 111-120, doi:10.5194/os-11-111-2015, 2015. 1294, 1304

Quack, B., Atlas, E., Petrick, G., Stroud, V., Schauffler, S., and Wallace, D. W. R.: Oceanic bromoform sources for the tropical atmosphere, Geophys. Res. Lett., 31, L23S05, doi:10.1029/2004GL020597, 2004. 1304

10 Schimpf, U., Nagel, L., and Jähne, B.: The 2009 SOPRAN active thermography pilot experiment in the Baltic Sea, in: Gas Transfer at Water Surfaces 2010, edited by: Komori, S., McGillis, W., and Kurose, R., 358-367, doi:10.5281/zenodo.14956, 2011. 1293, 1294, 1304

Schooley, A. H.: A simple optical method of measuring the statistical distribution of water surface slopes, J. Opt. Soc. Am., 44, 37-40, doi:10.1364/JOSA.44.000037, 1954. 1295

15 Stilwell, D. J.: Directional energy spectra of the sea from photographs, J. Geophys. Res., 74, 1974-1986, doi:10.1029/JB074i008p01974, 1969. 1293

Wanninkhof, R.: Relationship between wind speed and gas exchange over the ocean, J. Geophys. Res., 97, 7373-7382, doi:10.1029/92JC00188, 1992. 1293

Wanninkhof, R., Asher, W. E., Ho, D. T., Sweeney, C., and McGillis, W. R.: Advances in quantifying air-sea gas exchange and environmental forcing, Annu. Rev. Marine Sci., 1, 213-244, doi:10.1146/annurev.marine.010908.163742, 2009. 1304

Zappa, C., Banner, M., Schultz, H., Corrada-Emmanuel, A., Wolff, L., and Yalcin, J.: Retrieval of short ocean wave slope using polarimetric imaging, Meas. Sci. Technol., 19, 055503, doi:10.1088/0957-0233/19/5/055503, 2008. 1293

Zappa, C. J., McGillis, W. R., Raymond, P. A., Edson, J. B., Hintsa, E. J., Zemmelink, H. J., Dacey, J. W. H., and Ho, D. T.: Environmental turbulent mixing controls on the airwater gas exchange in marine and aquatic systems, Geophys. Res. Lett., 34, L10601, doi:10.1029/2006GL028790, 2007. 1293

Zappa, C. J., Banner, M. L., Schultz, H., Gemmrich, J., Morison, R. P., LeBel, D., and Dickey, T.: 30
$\mathrm{COOH} 19$, doi:10.1029/2011JC007336, 2012. 1294, 1301
OSD

$12,1291-1325,2015$

Influence of natural

surfactants on short

wind waves in the

coastal Peruvian

waters

D. Kiefhaber et al.

\section{Title Page}

Abstract

Introduction

Conclusions

References

Tables

Figures

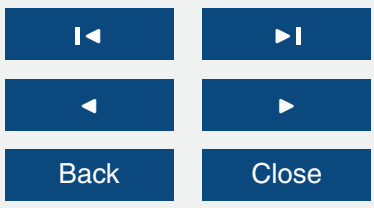

Full Screen / Esc

Printer-friendly Version

Interactive Discussion 
Table 1. Overview of results of mss measurements $\left(\sigma_{s}^{2}\right)$ along with position, wind direction $(\Phi)$ and wind speed $\left(U_{10}\right)$ measurements. For reference, the mss expectation from the CM clean parameterization $\left(\sigma_{\mathrm{s}, \mathrm{CM}}^{2}\right)$, as well as the reduction factor $(\epsilon)$ are given.

\begin{tabular}{|c|c|c|c|c|c|c|c|c|c|}
\hline Date & Time & Station & Lat & Lon & $\Phi\left[\left[^{\circ}\right]\right.$ & $U_{10}\left[\mathrm{~m} \mathrm{~s}^{-1}\right]$ & $\sigma_{\mathrm{s}}^{2}$ & $\sigma_{\mathrm{s}, \mathrm{CM}}^{2}$ & $\epsilon[\%]$ \\
\hline 3 Dec 2012 & $23: 11: 00$ & ME910/1715-2 & $5^{\circ} 0.02^{\prime} \mathrm{S}$ & $81^{\circ} 40.21^{\prime} \mathrm{W}$ & 171 & 7.9 & 0.031 & 0.045 & 69 \\
\hline 4 Dec 2012 & $06: 41: 00$ & ME910/1717-2 & $5^{\circ} 0.03^{\prime} \mathrm{S}$ & $81^{\circ} 19.81^{\prime} \mathrm{W}$ & 160 & 6.0 & 0.017 & 0.035 & 50 \\
\hline 4 Dec 2012 & $16: 43: 00$ & ME910/1719-2 & $6^{\circ} 11.52^{\prime} \mathrm{S}$ & $81^{\circ} 8.44^{\prime} \mathrm{W}$ & 154 & 4.9 & 0.018 & 0.029 & 62 \\
\hline 5 Dec 2012 & $12: 35: 00$ & ME910/1724-2 & $6^{\circ} 37.20^{\prime} \mathrm{S}$ & $81^{\circ} 49.80^{\prime} \mathrm{W}$ & 152 & 5.7 & 0.025 & 0.033 & 76 \\
\hline 6 Dec 2012 & 03:43:00 & ME910/1725-2 & $8^{\circ} 37.87^{\prime} \mathrm{S}$ & $81^{\circ} 0.02^{\prime} \mathrm{W}$ & 181 & 5.0 & 0.023 & 0.029 & 77 \\
\hline 6 Dec 2012 & 15:18:00 & ME910/1727-2 & $8^{\circ} 18.67^{\prime} \mathrm{S}$ & $80^{\circ} 24.62^{\prime} \mathrm{W}$ & 143 & 2.0 & 0.011 & 0.014 & 83 \\
\hline 7 Dec 2012 & $23: 56: 00$ & ME910/1733-2 & $9^{\circ} 28.81^{\prime} \mathrm{S}$ & $79^{\circ} 16.81^{\prime} \mathrm{W}$ & 154 & 5.0 & 0.025 & 0.029 & 87 \\
\hline 8 Dec 2012 & 03:58:00 & ME910/1733-3 & $9^{\circ} 29.52^{\prime} \mathrm{S}$ & $79^{\circ} 17.07^{\prime} \mathrm{W}$ & 155 & 4.4 & 0.020 & 0.026 & 78 \\
\hline 8 Dec 2012 & 08:03:00 & ME910/1733-4 & $9^{\circ} 30.24^{\prime} \mathrm{S}$ & $79^{\circ} 17.39^{\prime} \mathrm{W}$ & 169 & 3.9 & 0.018 & 0.023 & 78 \\
\hline 8 Dec 2012 & $11: 58: 00$ & ME910/1733-7 & $9^{\circ} 31.27^{\prime} \mathrm{S}$ & $79^{\circ} 17.89^{\prime} \mathrm{W}$ & 139 & 3.8 & 0.019 & 0.023 & 83 \\
\hline 9 Dec 2012 & $12: 58: 00$ & ME910/1736-2 & $9^{\circ} 55.82^{\prime} \mathrm{S}$ & $80^{\circ} 13.83^{\prime} \mathrm{W}$ & 145 & 6.7 & 0.022 & 0.038 & 57 \\
\hline 10 Dec 2012 & $02: 48: 00$ & ME910/1737-2 & $11^{\circ} 28.24^{\prime} \mathrm{S}$ & $79^{\circ} 25.79^{\prime} \mathrm{W}$ & 143 & 7.7 & 0.030 & 0.043 & 69 \\
\hline 10 Dec 2012 & $14: 13: 00$ & ME910/1739-2 & $11^{\circ} 7.25^{\prime} \mathrm{S}$ & $78^{\circ} 50.97^{\prime} \mathrm{W}$ & 146 & 5.6 & 0.019 & 0.032 & 58 \\
\hline 11 Dec 2012 & 01:05:00 & ME910/1741-2 & $10^{\circ} 46.82^{\prime} \mathrm{S}$ & $78^{\circ} 16.21^{\prime} \mathrm{W}$ & 153 & 6.0 & 0.021 & 0.035 & 61 \\
\hline 13 Dec 2012 & $00: 34: 00$ & ME910/1751-2 & $12^{\circ} 2.41^{\prime} \mathrm{S}$ & $79^{\circ} 0.02^{\prime} \mathrm{W}$ & 144 & 6.5 & 0.031 & 0.037 & 84 \\
\hline 13 Dec 2012 & $12: 04: 00$ & ME910/1752-3 & $12^{\circ} 55.23^{\prime} \mathrm{S}$ & $78^{\circ} 42.00^{\prime} \mathrm{W}$ & 143 & 5.9 & 0.024 & 0.034 & 72 \\
\hline 14 Dec 2012 & $00: 30: 00$ & ME910/1752-10 & $12^{\circ} 55.23^{\prime} \mathrm{S}$ & $78^{\circ} 42.03^{\prime} \mathrm{W}$ & 144 & 5.9 & 0.027 & 0.034 & 79 \\
\hline 14 Dec 2012 & $05: 31: 00$ & ME910/1752-11 & $12^{\circ} 55.26^{\prime} \mathrm{S}$ & $78^{\circ} 42.05^{\prime} \mathrm{W}$ & 146 & 6.0 & 0.028 & 0.034 & 81 \\
\hline 15 Dec 2012 & $00: 42: 00$ & ME910/1755-3 & $12^{\circ} 25.23^{\prime} \mathrm{S}$ & $77^{\circ} 48.60^{\prime} \mathrm{W}$ & 155 & 6.2 & 0.027 & 0.036 & 75 \\
\hline 15 Dec 2012 & 07:06:00 & ME910/1756-2 & $12^{\circ} 15.03^{\prime} \mathrm{S}$ & $77^{\circ} 31.21^{\prime} \mathrm{W}$ & 145 & 3.2 & 0.018 & 0.020 & 92 \\
\hline 16 Dec 2012 & $13: 09: 00$ & ME910/1760-2 & $12^{\circ} 50.44^{\prime} \mathrm{S}$ & $76^{\circ} 40.78^{\prime} W$ & 351 & 1.8 & 0.014 & 0.012 & 116 \\
\hline 20 Dec 2012 & $10: 21: 00$ & ME910/1772-2 & $15^{\circ} 53.52^{\prime} \mathrm{S}$ & $77^{\circ} 3.45^{\prime} \mathrm{W}$ & 154 & 7.2 & 0.034 & 0.041 & 84 \\
\hline 21 Dec 2012 & $21: 15: 00$ & ME910/1774-2 & $16^{\circ} 1.14^{\prime} \mathrm{S}$ & $76^{\circ} 30.73^{\prime} \mathrm{W}$ & 142 & 9.1 & 0.040 & 0.051 & 79 \\
\hline 22 Dec 2012 & 04:06:00 & ME910/1775-2 & $15^{\circ} 50.99^{\prime} \mathrm{S}$ & $76^{\circ} 12.15^{\prime} \mathrm{W}$ & 143 & 8.1 & 0.047 & 0.045 & 103 \\
\hline 22 Dec 2012 & $10: 58: 00$ & ME910/1776-2 & $15^{\circ} 41.46^{\prime} \mathrm{S}$ & $75^{\circ} 54.01^{\prime} \mathrm{W}$ & 156 & 5.9 & 0.028 & 0.034 & 82 \\
\hline 22 Dec 2012 & $18: 34: 00$ & ME910/1777-3 & $15^{\circ} 31.19^{\prime} \mathrm{S}$ & $75^{\circ} 36.03^{\prime} \mathrm{W}$ & 161 & 3.7 & 0.015 & 0.023 & 64 \\
\hline 23 Dec 2012 & $00: 31: 00$ & ME910/1777-6 & $15^{\circ} 32.46^{\prime} \mathrm{S}$ & $75^{\circ} 37.36^{\prime} \mathrm{W}$ & 145 & 8.3 & 0.036 & 0.046 & 77 \\
\hline 23 Dec 2012 & $06: 34: 00$ & ME910/1777-8 & $15^{\circ} 33.65^{\prime} \mathrm{S}$ & $75^{\circ} 37.77^{\prime} \mathrm{W}$ & 147 & 7.0 & 0.031 & 0.040 & 78 \\
\hline 23 Dec 2012 & $12: 34: 00$ & ME910/1777-9 & $15^{\circ} 35.19^{\prime} \mathrm{S}$ & $75^{\circ} 38.24^{\prime} \mathrm{W}$ & 140 & 7.8 & 0.030 & 0.044 & 68 \\
\hline 23 Dec 2012 & $20: 39: 00$ & ME910/1778-2 & $15^{\circ} 22.83^{\prime} \mathrm{S}$ & $75^{\circ} 20.04^{\prime} \mathrm{W}$ & 133 & 5.6 & 0.024 & 0.032 & 73 \\
\hline
\end{tabular}

12, 1291-1325, 2015

Influence of natural surfactants on short wind waves in the coastal Peruvian waters

D. Kiefhaber et al.

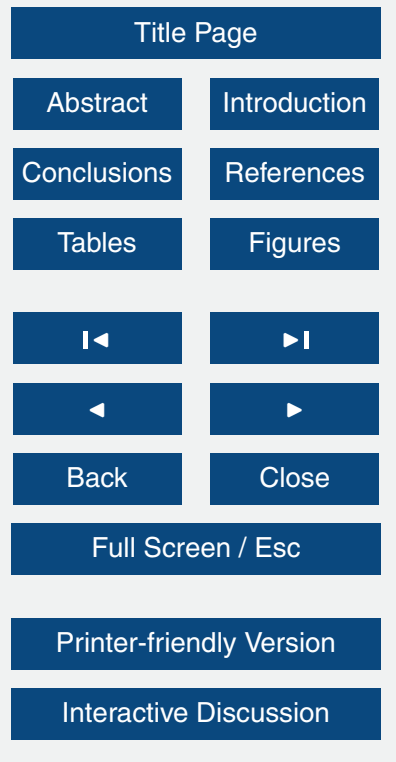

Interactive Discussion 


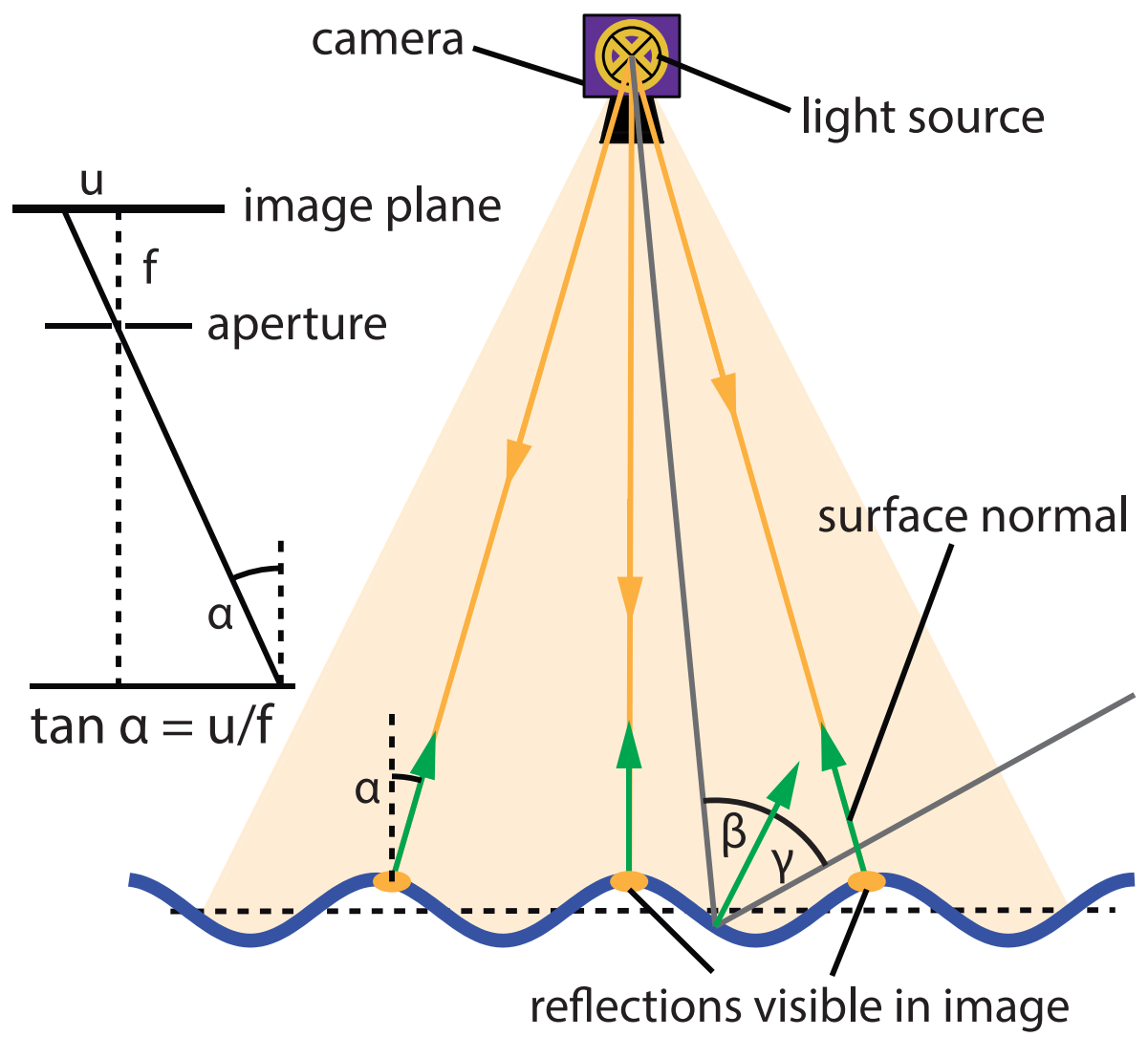

Figure 1. Sketch of the wave slope measurement method: a camera is observing specular reflections of a light source that is placed at virtually the same location. Reflections are only visible for a specific value of the wave slope (which depends on the position in the image).
OSD

12, 1291-1325, 2015

\section{Influence of natural surfactants on short wind waves in the coastal Peruvian waters \\ D. Kiefhaber et al.}

\section{Title Page}

Abstract

Introduction

Conclusions

References

Tables

Figures

14

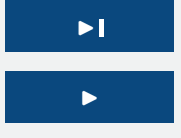

Back

Close

\section{Full Screen / Esc}

Printer-friendly Version

Interactive Discussion 

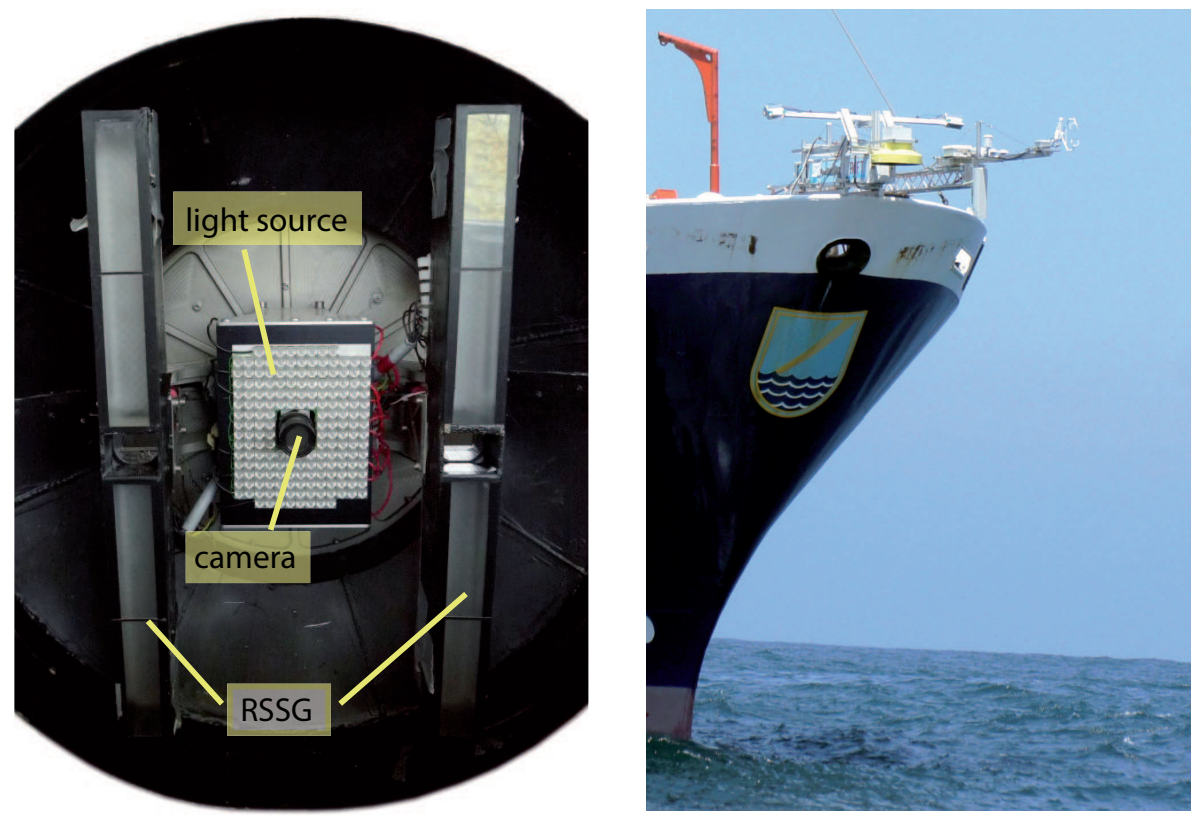

Figure 2. Left: camera and light source for the slope PDF measurement are integrated into the Reflective Stereo Slope Gauge (RSSG) with its two line shaped light sources and cameras. Right: the instrumentation on the bow of R/V Meteor during M91. The wave slope instruments are located under the yellow rain cover.

\section{OSD}

$12,1291-1325,2015$

Influence of natural surfactants on short wind waves in the coastal Peruvian waters

D. Kiefhaber et al.

\section{Title Page}

\section{Abstract}

Conclusions

Tables

14

Back

Full Screen / Esc

Printer-friendly Version

Interactive Discussion

(n)
Introduction

References

Figures

$>$ I

Close

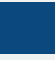



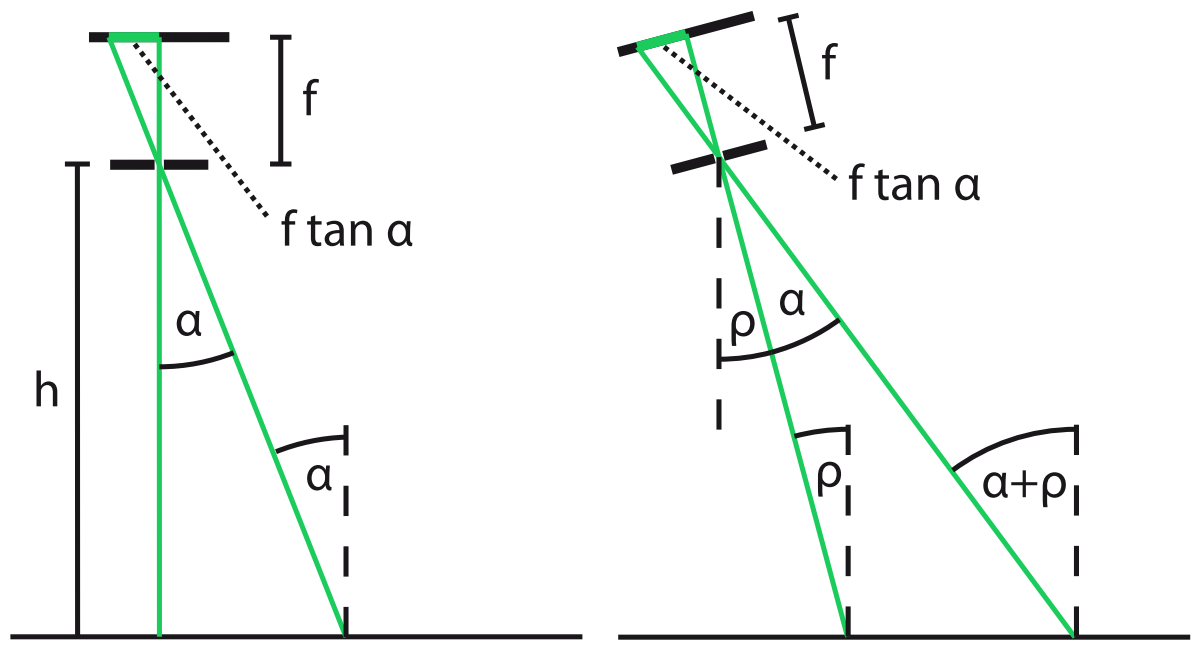

OSD

12, 1291-1325, 2015

Influence of natural surfactants on short wind waves in the coastal Peruvian waters

D. Kiefhaber et al.

\section{Title Page}

\section{Abstract}

Introduction

Conclusions

References

Tables

Figures

14

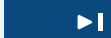

Figure 3. The effect of roll on the measurement geometry.

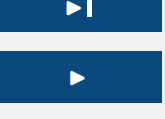

\section{Full Screen / Esc}

Printer-friendly Version

Interactive Discussion 

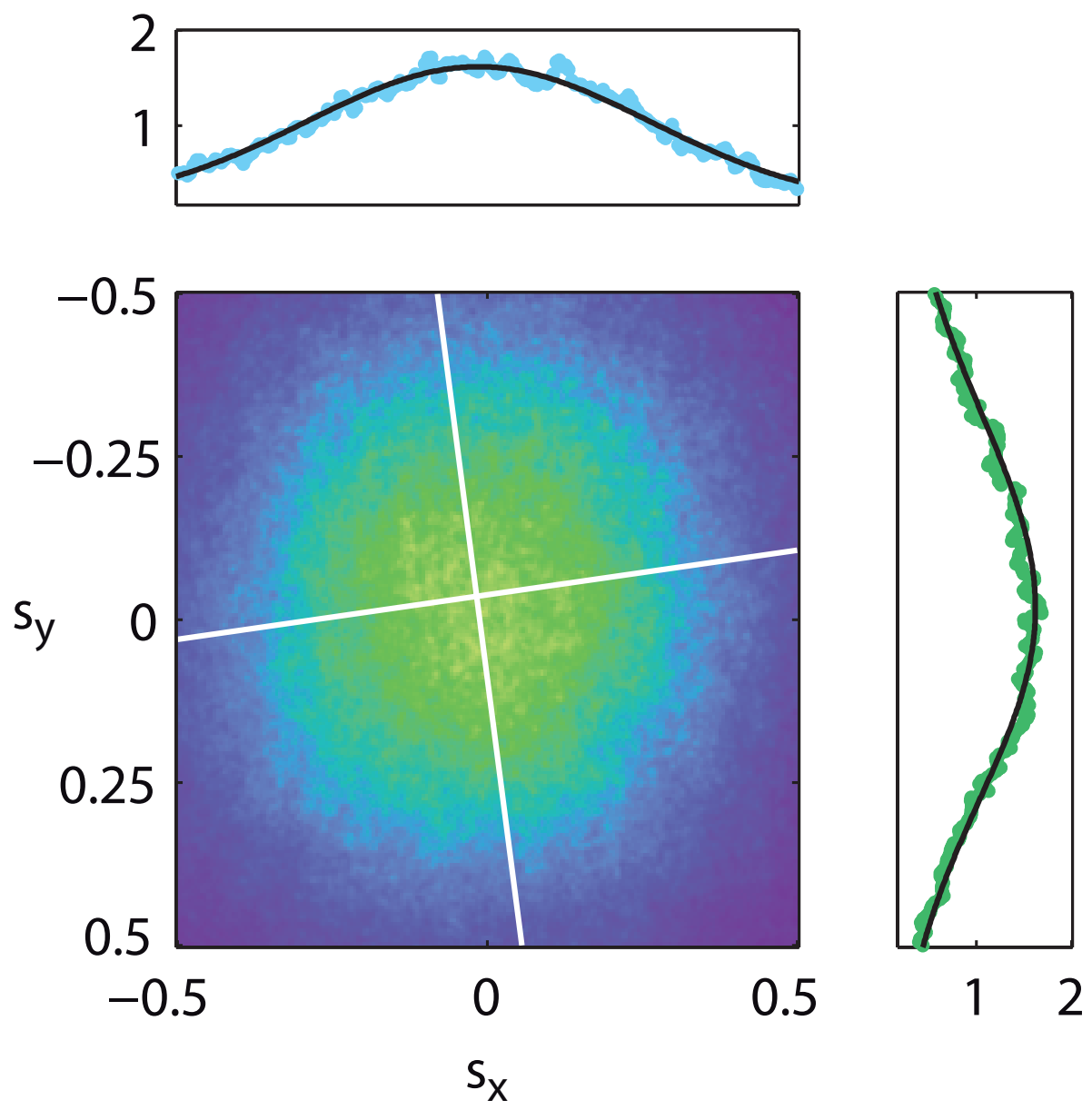

Figure 4. Example PDF measurement with fitted Gram-Charlier model function (black lines in profiles). The wind is blowing from above along the almost vertical white line.

\section{OSD}

$12,1291-1325,2015$

\section{Influence of natural surfactants on short wind waves in the coastal Peruvian waters \\ D. Kiefhaber et al.}

\section{Title Page}

\section{Abstract}

Introduction

Conclusions

References

Tables

Figures

14

4

Back

Close

Full Screen / Esc

Printer-friendly Version

Interactive Discussion 


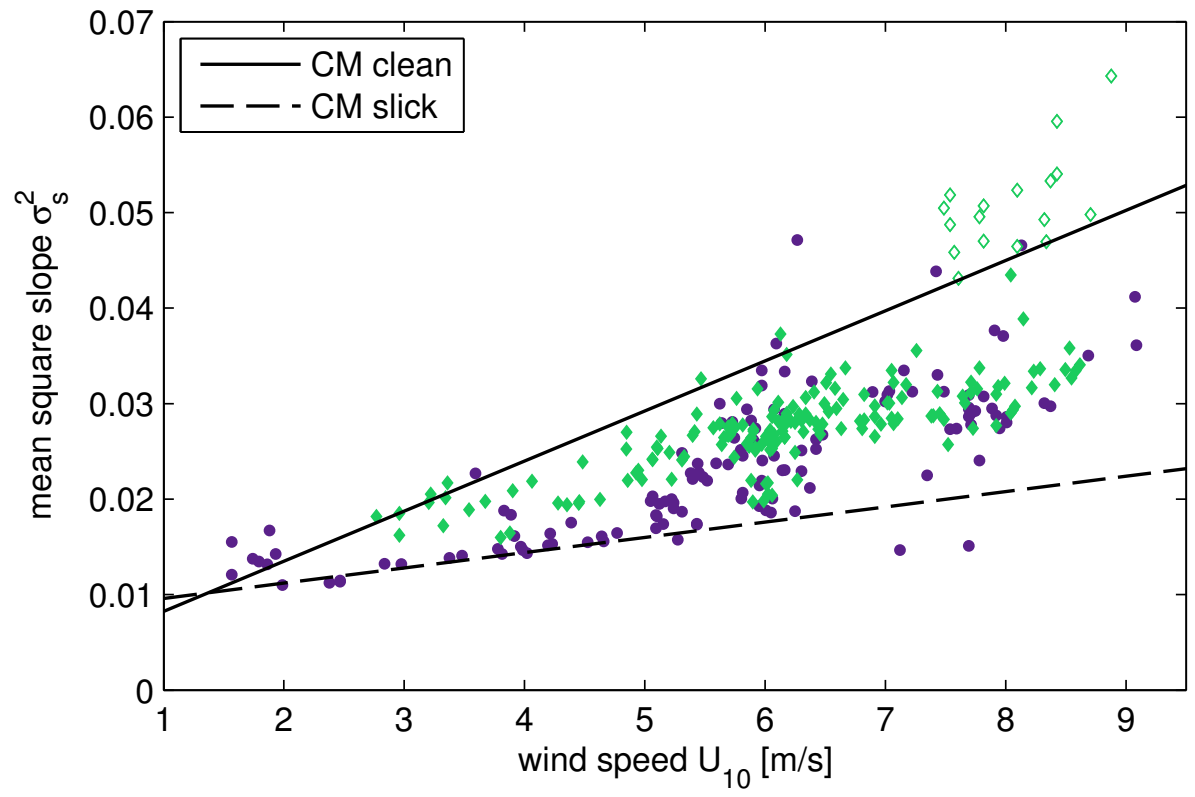

Figure 5. All mss measurements for M91. Diamonds are direct slope PDF measurements, circles are calibrated RSSG mss measurements. The solid and dashed lines are the Cox and Munk (1954b) parameterizations for clean water and slicks, respectively.
OSD

12, 1291-1325, 2015

Influence of natural surfactants on short wind waves in the coastal Peruvian waters

D. Kiefhaber et al.

\section{Title Page}

\section{Abstract}

Introduction

Conclusions

References

Tables

Figures

14

\section{Full Screen / Esc}

Printer-friendly Version

Interactive Discussion 


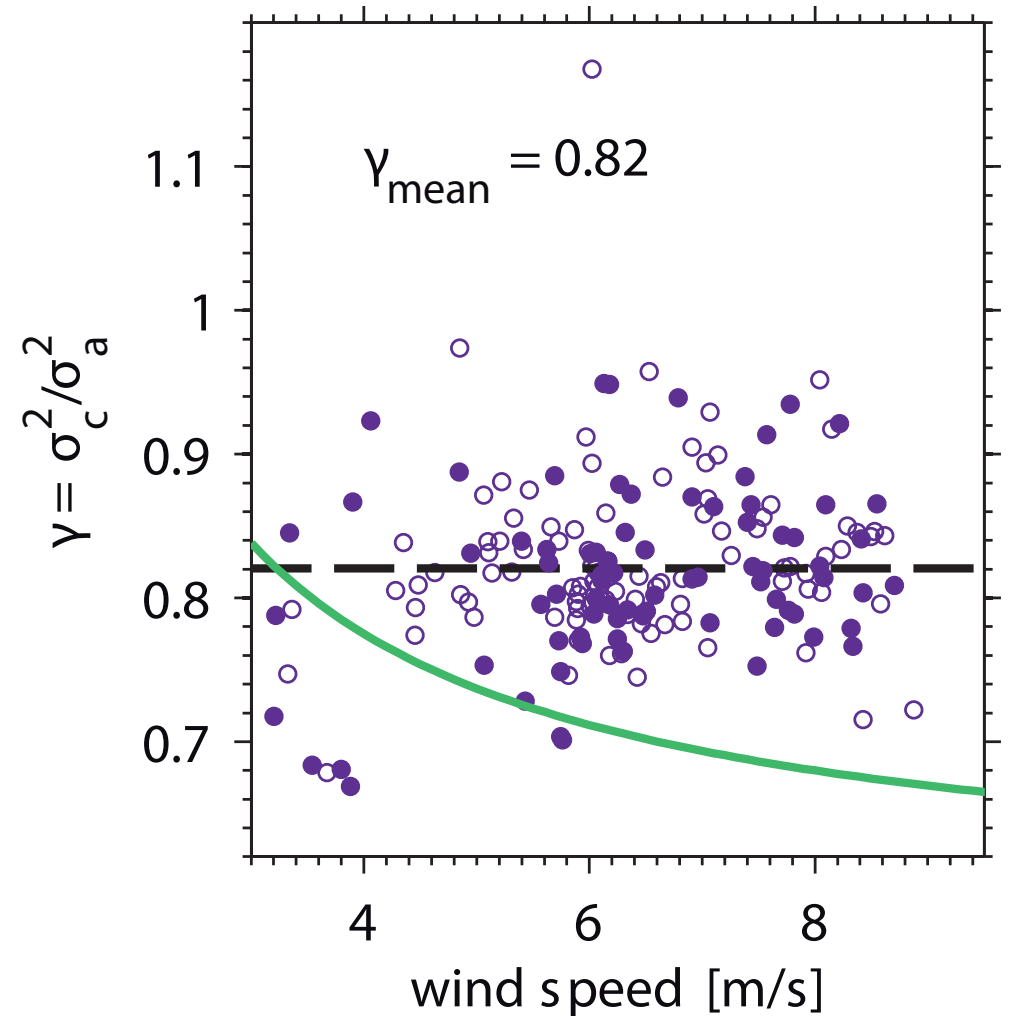

Figure 6. Anisotropy between the alongwind and crosswind mss. The green line is the Bréon and Henriot (2006) parameterization given by Munk (2009). The data are divided evenly into higher wind variability (solid) and lower wind variability subsets. No clear trend is visible.
OSD

$12,1291-1325,2015$

Influence of natural surfactants on short wind waves in the coastal Peruvian waters

D. Kiefhaber et al.

\section{Title Page}

Abstract

Introduction

Conclusions

References

Tables

Figures

14

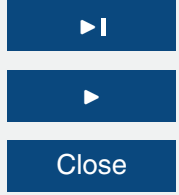

Back

Full Screen / Esc

Printer-friendly Version

Interactive Discussion 


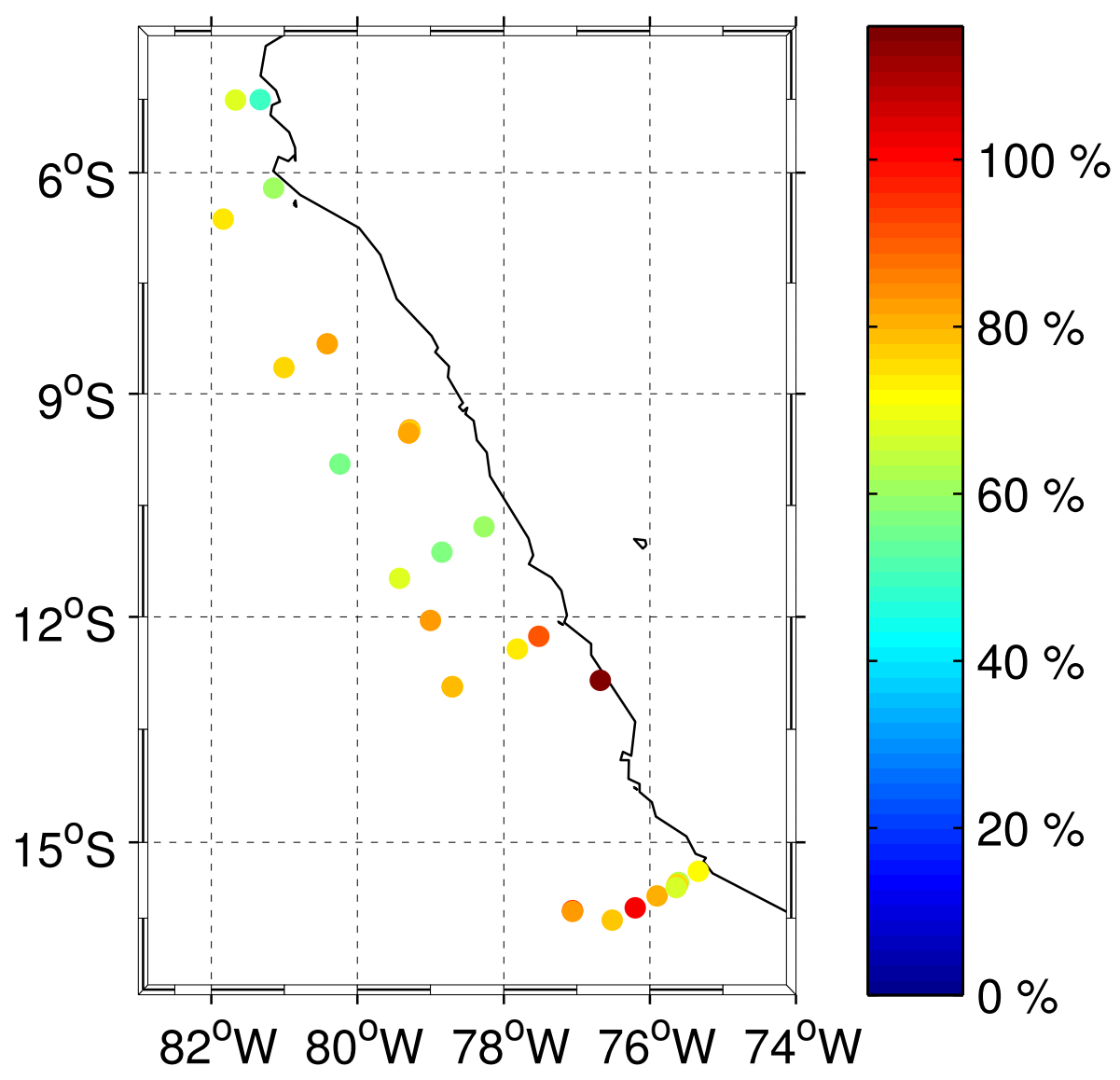

Figure 7. All processed stations. Color code is the $\epsilon$ value from Table 1 .

\section{OSD}

12, 1291-1325, 2015

Influence of natural surfactants on short wind waves in the coastal Peruvian waters

D. Kiefhaber et al.

\section{Title Page}

Abstract

Introduction

Conclusions

References

Tables

Figures

14

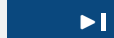

4

Back

Close

\section{Full Screen / Esc}

Printer-friendly Version

Interactive Discussion 


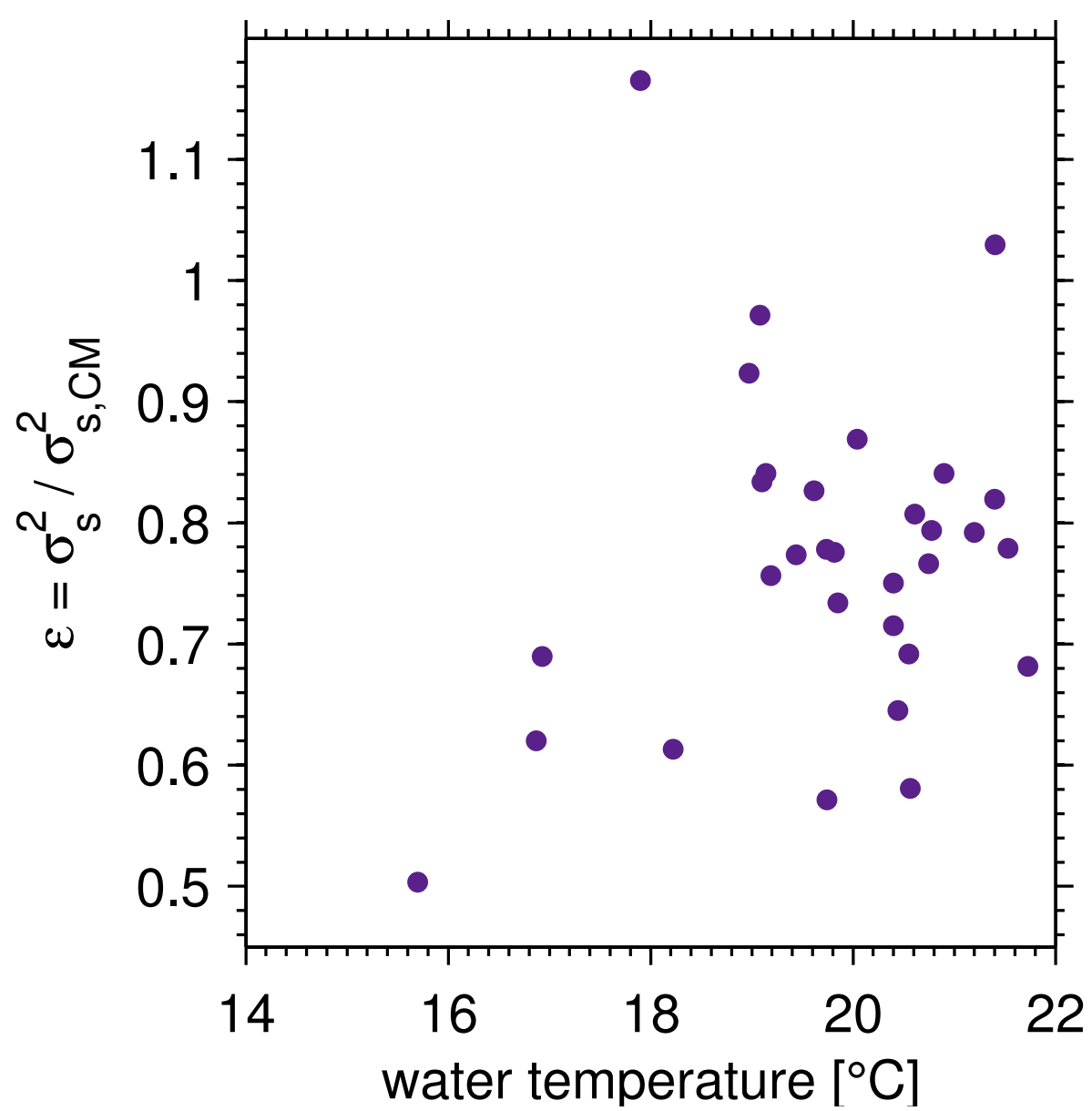

Figure 8. The impact of water temperature as a proxy for upwelling on the fraction of mss and its $\mathrm{CM}$ prediction $(\epsilon)$ for the 30 stations.

\section{OSD}

12, 1291-1325, 2015

Influence of natural surfactants on short wind waves in the coastal Peruvian waters

D. Kiefhaber et al.

\section{Title Page}

Abstract

Introduction

Conclusions

References

Tables

Figures

14

Back

Close

\section{Full Screen / Esc}

Printer-friendly Version

Interactive Discussion 


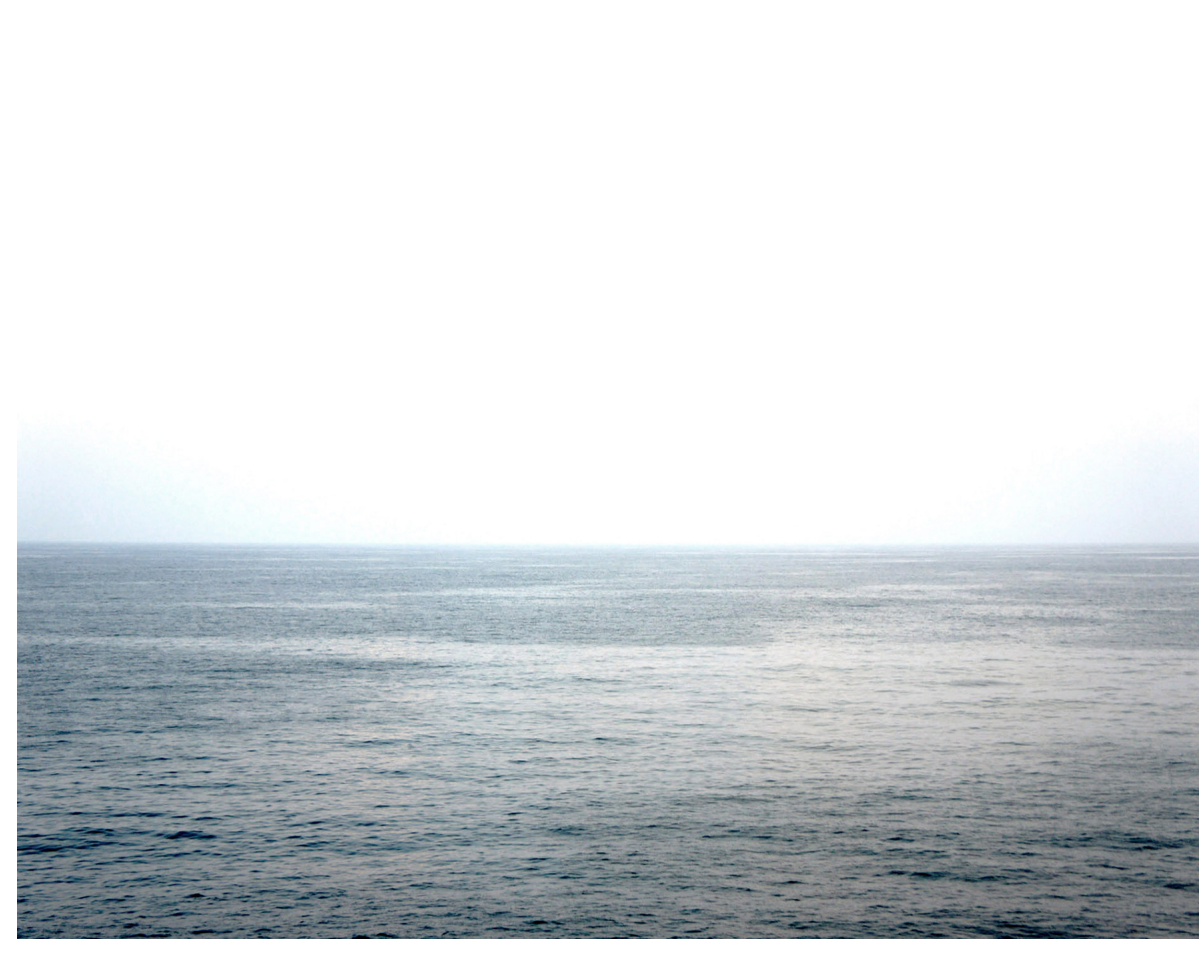

Figure 9. Example for a patchy distribution of surface films. Water surface patches affected by surface films have reduced roughness and appear smoother in the image.

\section{OSD}

$12,1291-1325,2015$

\section{Influence of natural surfactants on short wind waves in the coastal Peruvian waters \\ D. Kiefhaber et al.}

\section{Title Page}

Abstract

Introduction

Conclusions

References

Tables

Figures

14

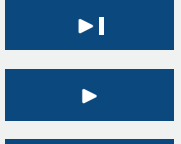

Back

Close

Full Screen / Esc

Printer-friendly Version

Interactive Discussion 


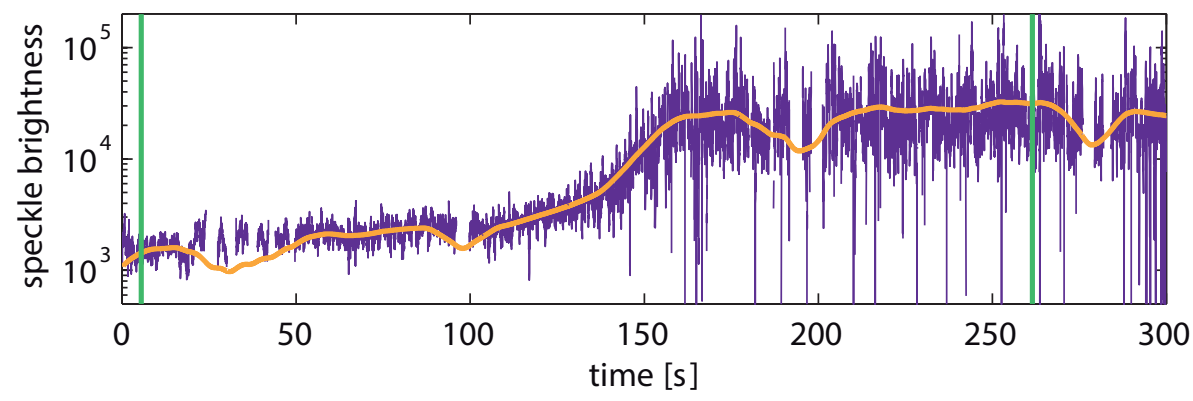

Figure 10. Example for rapid change of surface roughness. Shown is a time series the mean speckle brightness in the images, which increases by more than an order of magnitude about $150 \mathrm{~s}$ into the measurement run as the ship enters a surface film patch.

\section{OSD}

12, 1291-1325, 2015

\section{Influence of natural surfactants on short wind waves in the coastal Peruvian waters \\ D. Kiefhaber et al.}

\section{Title Page}

\section{Abstract}

Introduction

Conclusions

References

Tables

Figures

14

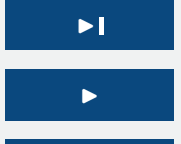

Back

Close

Full Screen / Esc

Printer-friendly Version

Interactive Discussion 


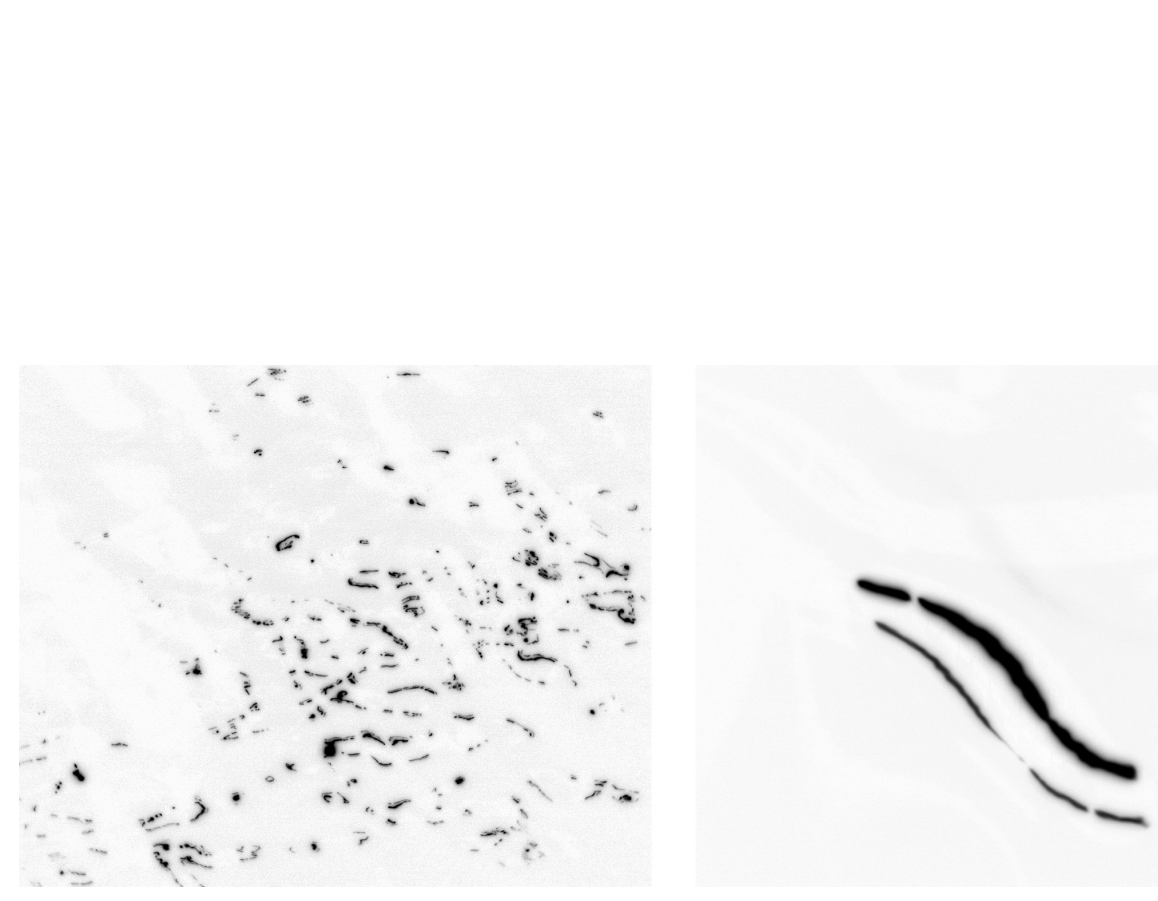

OSD

12, 1291-1325, 2015

Influence of natural surfactants on short wind waves in the coastal Peruvian waters

D. Kiefhaber et al.

\section{Title Page}

Figure 11. RSSG images taken before (left) and after (right) entering the slick patch. The images have an inverted gray scale showing speckles as dark spots on white background. They were taken at the times marked by the green lines in Fig. 10.

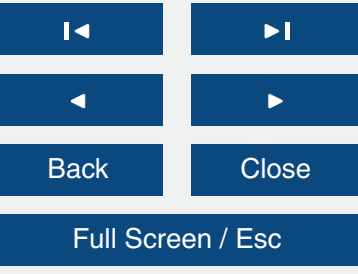

Printer-friendly Version

Interactive Discussion 


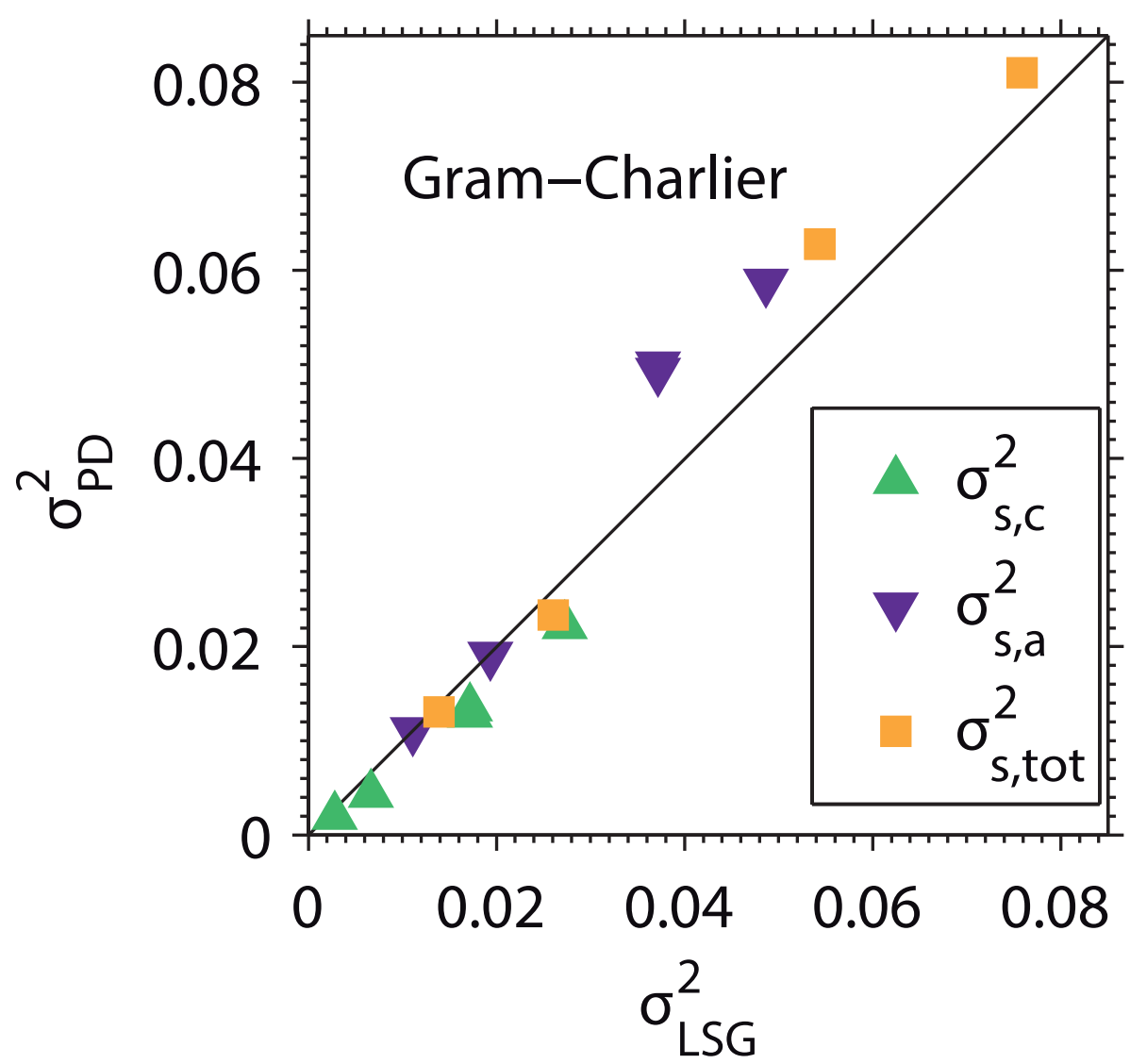

Figure 12. Comparison of mean square slope measurements with reflective system to data from a Laser slope gauge (LSG) in the Marseille facility. Shown are the total mss (squares), the alongwind mss (downward triangles) as well as the crosswind mss (upward trinangles).
OSD

12, 1291-1325, 2015

\section{Influence of natural surfactants on short wind waves in the coastal Peruvian waters \\ D. Kiefhaber et al.}

\section{Title Page}

Abstract

Introduction

Conclusions

References

Tables

Figures

14

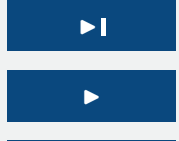

Back

Close

\section{Full Screen / Esc}

Printer-friendly Version

Interactive Discussion 


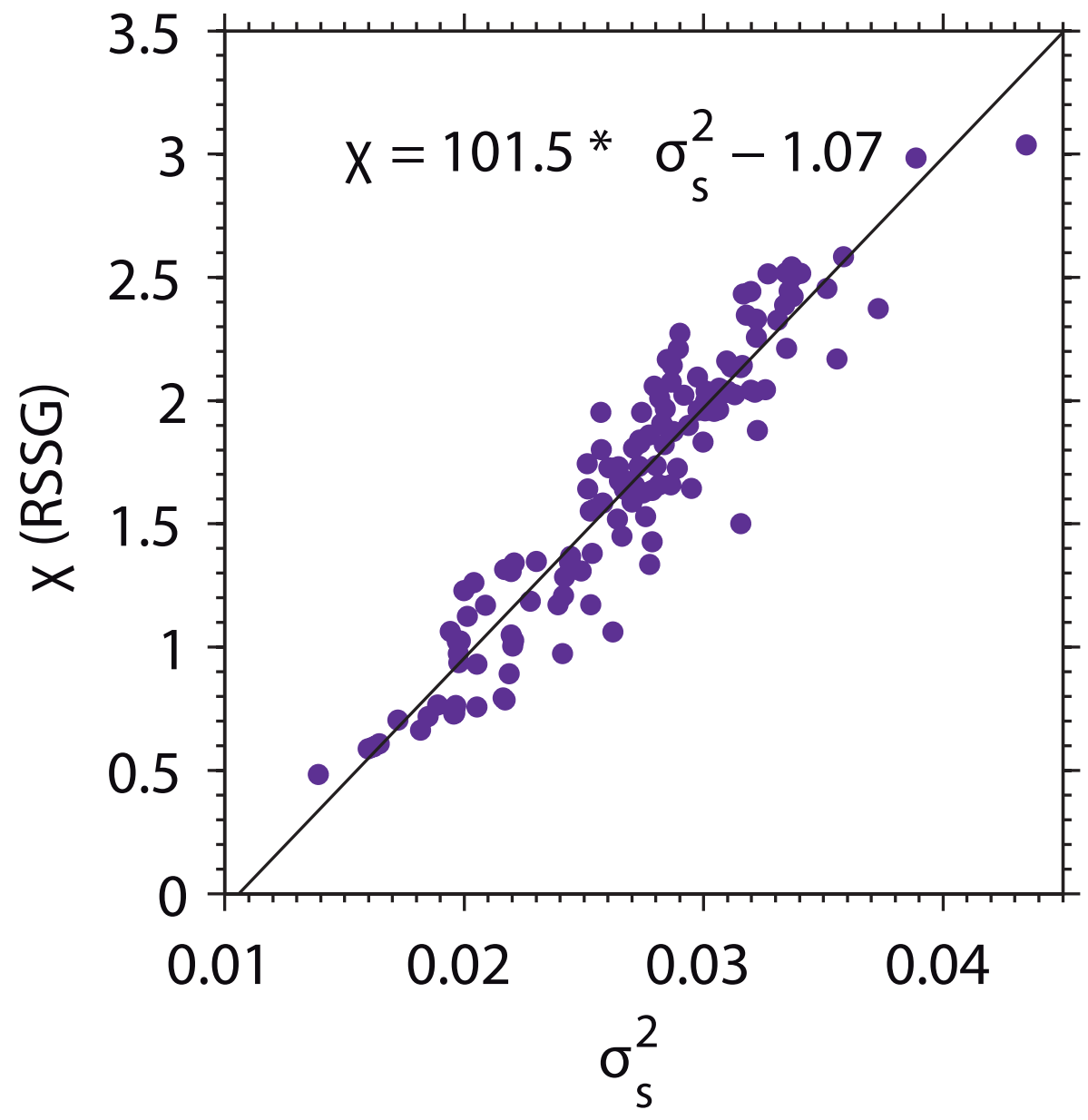

Figure 13. Calibration of the RSSG surface roughness parameter $(\chi)$ against the mss measurements from probability distributions.
OSD

12, 1291-1325, 2015

Influence of natural surfactants on short wind waves in the coastal Peruvian waters

D. Kiefhaber et al.

\section{Title Page}

Abstract

Introduction

Conclusions

References

Tables

Figures

14

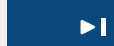

4

Back

Close

Full Screen / Esc

Printer-friendly Version

Interactive Discussion 